\title{
Toxicological hazard induced by sucralose to environmentally relevant concentrations in common carp (Cyprinus carpio)
}

\author{
Karinne Saucedo-Vence a , Armando Elizalde-Velázquez a , Octavio Dublán-García a , Marcela Galar-Martínez b , \\ Hariz Islas-Flores ${ }^{a}$, Nely SanJuan-Reyes ${ }^{\text {a }}$, Sandra García-Medina ${ }^{\text {b }}$, \\ María Dolores Hernández-Navarro a , Leobardo Manuel Gómez-Oliván ${ }^{\mathrm{a}, *}$

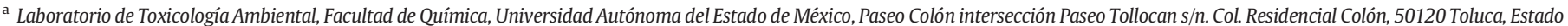
de México, Mexico Massieu Esq. Cda. Miguel Stampa s/n, Delegación Gustavo A. Madero, México, DF CP 07738, Mexico
}

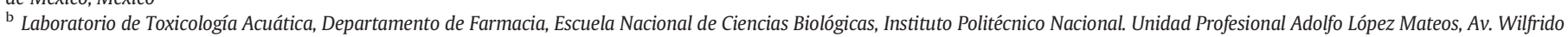

\section{H I G H L I G H T S}

- Sucralose was detected and quantified in different organs of Cyprinus carpio.

- Sucralose is not bio-accumulated in the organs and tissues of Cyprinus carpio.

- Sucralose induces the SOD and CAT activity in gills, muscle and brain of Cyprinus carpio.

- Sucralose induces damage to lipids and proteins in gills, muscle, brain and liver of Cyprinus carpio.

\section{G R A P H I C A L A B S T R A C T}

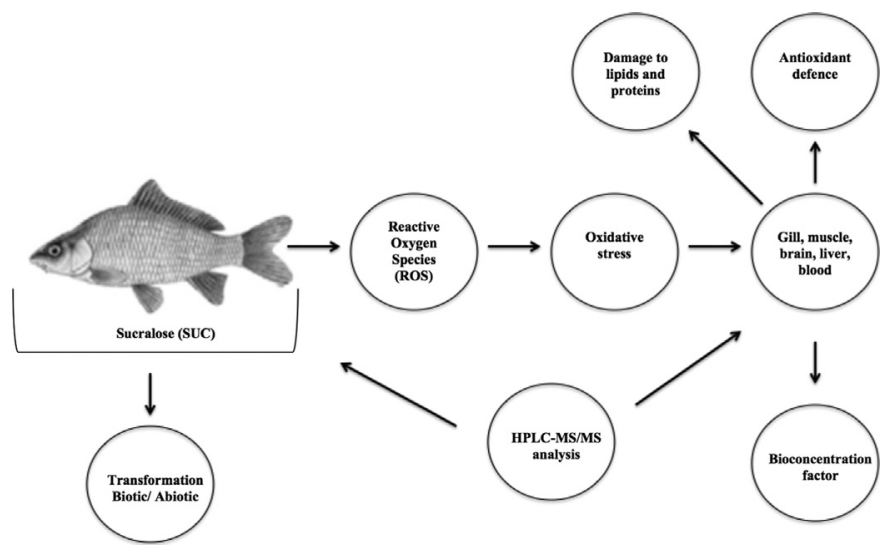

\section{A B S T R A C T}

Sucralose (SUC) is an artificial sweetener that is now widely used in North American and Europe; it has been detected in a wide variety of aquatic environments. It is considered safe for human consumption but its effects in the ecosystem have not yet been studied in depth, since limited ecotoxicological data are available in the peerreviewed literature. This study aimed to evaluate potential SUC-induced toxicological hazard in the blood, brain, gill, liver and muscle of Cyprinus carpio using oxidative stress biomarkers. Carps were exposed to two different environmentally relevant concentrations $\left(0.05\right.$ and $\left.155 \mu \mathrm{g} \mathrm{L}{ }^{-1}\right)$ for different exposure times $(12,24,48,72$

Abbreviations: AChE, acetylcholinesterase; ACS, acesulfame; AGE, advanced glycation end product; ALI, alitame; ANOVA, analysis of variance; ASP, aspartame; BCF, bioaccumulation

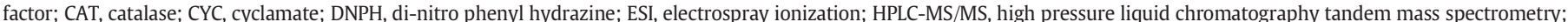

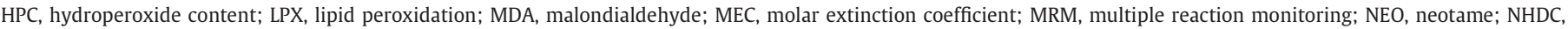

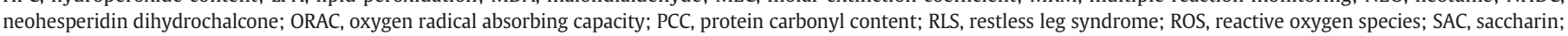
SOD, superoxide dismutase; SUC, sucralose; TBA, thiobarbituric acid; TCA, trichloroacetic acid.

* Corresponding author at: Laboratorio de Toxicología Ambiental, Facultad de Química, Universidad Autónoma del Estado de México, Paseo Colón intersección Paseo Tollocan s/n. Col. Residencial Colón, Toluca CP 50120, Estado de México, Mexico.

E-mail addresses: Imgomezo@uaemex.mx, lgolivan74@gmail.com (L.M. Gómez-Oliván). 
Keywords:

Sucralose

Cyprinus carpio

Oxidative stress

LC-MS/MS

Bioconcentration and $96 \mathrm{~h}$ ). The following biomarkers were evaluated: lipid peroxidation (LPX), hydroperoxide content (HPC) and protein carbonyl content (PCC), as well as the activity of antioxidant enzymes, superoxide dismutase (SOD) and catalase (CAT). SUC was determined by high pressure liquid chromatography tandem mass spectrometry techniques (HPLC)-MS/MS. Results show a statically significant increase in LPX, HPC, PCC $(\mathrm{P}<0.05)$ especially in gill, brain and muscle, as well as significant changes in the activity of antioxidant enzymes in gill and muscle. Furthermore, the biomarkers employed in this study are useful in the assessment of the environmental impact of this agent on aquatic species.

(c) 2016 Elsevier B.V. All rights reserved.

\section{Introduction}

Artificial sweeteners are used worldwide as sugar substitutes in remarkable amounts in food, beverages, and also in drugs and sanitary products, such as mouthwashes. They provide no or negligible energy and thus are ingredients of dietary products (Kroger et al., 2006; Zygler et al., 2009). The most popular artificial sweeteners are aspartame (ASP), neotame (NEO), alitame (ALI), acesulfame (ACS), saccharin (SAC), cyclamate (CYC), sucralose (SUC), and neohesperidin dihydrochalcone (NHDC). Of the variety of artificial sweeteners being used, only ACS, CYC, SAC and SUC have been identified in wastewater effluents (Lange et al., 2012).

Artificial sweeteners are highly consumed, particularly in the U.S., with increasing trends in consumption, especially after the introduction of SUC in 1998. The global market for artificial sweeteners reaches \$5.1 billion, of which the U.S. and Europe currently make up 65\% (Bennett, 2008). Production volumes of artificial sweeteners vary between reports. The U.S. is currently the largest market for SUC, making use of more than 1500 tons per year, followed by Europe, with around 400 tons per year, as reported by a major Chinese company that recently entered into the SUC market. In the Asian Pacific market, the volume output in total of SAC, CYC, ACS, ASP, SUC, ALI and NEO, grew approximately 10\% between 2009 and 2010, reaching approximately 109,000 tons per year (Kokotou et al., 2012). SUC constituted about $16 \%$ of the U.S. high intensity sweeteners market in 2009 , and its growth is expected to be high, almost $5 \%$ annually, through the next few years (Haely, 2012).

Although from the beginning of their use there have been controversies over their risk as potential carcinogens (Weihrauch and Diehl, 2004), these sweetener compounds are generally considered to be safe for use in foodstuffs (Cohen et al., 2008; Kroger et al., 2006; Ahmed and Thomas, 1992). Moreover, due to these compounds are metabolically inert in the human body it has been believed that are also inert in the environment. However in recent years the concern is shifting from health concerns to ecosystem concerns (Sang et al., 2014).

Excretion after human consumption is undoubtedly a major source of artificial sweeteners in the environment, but it is surely not the only one (Kokotou et al., 2012). From households and industries, all artificial sweeteners enter into wastewater treatment plants, where in most cases passes without any change through these processes, as a result they eventually reside in the receiving environmental water bodies (Houtman, 2010). In addition, direct discharges from industry, households, animal farming and agriculture burden surface waters with artificial sweeteners (Houtman, 2010).

SUC (also known as Splenda) is a relatively new artificial sweetener that is now widely used in North American and Europe. SUC is produced by the chlorination of sucrose, which leads to a stabile compound that is poorly absorbed in the mammalian gastro-intestinal (GI) tract. The majority of orally ingested sucralose is excreted as unchanged parent compound, with $<1 \%$ of the original oral dose excreted as two glucuronide adduct metabolites (Sims et al., 2000). It may seem like an odd compound to include as an emerging contaminant, but it is now being found in environmental waters and it is extremely persistent (half-life up to several years) (Richardson, 2010).
Sucralose has been detected in a wide variety of aquatic environments. A Swedish study reported concentrations of SUC in treated effluent to be $\leq 11 \mu \mathrm{g} \mathrm{L}{ }^{-1}$, while surface water concentrations were $\leq 3.6 \mu \mathrm{g}$ $\mathrm{L}^{-1}$ (Brorstrom-Lunden et al., 2008). Other studies have measured sucralose in effluents in surface waters at concentrations $\leq 2.5 \mu \mathrm{g} \mathrm{L}^{-1}$ (Ferrer and Thurman, 2010; Neset et al., 2010; Loos et al., 2009; Scheurer et al., 2009). One hundred and twenty samples were collected from rivers in 27 European countries, and sucralose was found up to $1 \mu \mathrm{g}$ $\mathrm{L}^{-1}$, predominantly in samples from the United Kingdom, Belgium, The Netherlands, France, Switzerland, Spain, Italy, Norway, and Sweden, with only minor levels $\left(<100 \mathrm{ng} \mathrm{L}^{-1}\right)$ detected in samples from Germany and Eastern Europe, suggesting a lower use of sucralose in those countries (Richardson and Ternes, 2011).

SUC is considered safe for human consumption (the acceptable daily intake for SUC was set at $5 \mathrm{mg} \mathrm{kg}^{-1}$ of body weight per day) (Grotz and Munro, 2009; Brusick et al., 2010; Viberg and Fredriksson, 2011), but its effects in the ecosystem have not yet been studied in depth, since limited ecotoxicological data are available in the scientific literature. Hjorth et al. (2010) evaluated egg production, hatching rate, food intake and mortality of two species of copepods, Calanus glacialis and Calanus finmarchicus exposed to six different concentrations $\left(0-50 \mathrm{mg} \mathrm{L}^{-1}\right)$ of SUC. The results showed that both species responded weakly to SUC, but with $C$. glacialis being possibly slightly more sensitive than $C$. finmarchicus. Huggett and Stoddard (2011) assessed the effects of SUC on the survival, growth and reproduction of Daphnia magna and Americamysis bahia (mysid shrimp). They concluded that the concentrations of SUC detected in the environment are well below those required to elicit chronic effects in freshwater or marine water bodies. On the other hand, recently, a study on crustaceans showed for the first time that physiology and locomotive behaviour could be affected by exposure to SUC $\left(0.0001-5 \mathrm{mg} \mathrm{L}^{-1}\right)$. The behavioural response of Daphnia magna manifested as altered swimming height and increased swimming speed, whereas in gammarids the time to reach food and shelter was prolonged. These authors suggest that exposure to sucralose may induce neurological and oxidative mechanisms with potentially important consequences for D. magna behaviour and physiology (ErikssonWiklund et al., 2014). Research on the ecotoxicology of SUC is expected to increase in next years, since both short and long-term effects resulting from exposure to low levels of this compound is largely unknown.

Biomarkers are measurable internal indicators of changes in organisms at the molecular or cellular level, which can offer great potential to understand the environmentally mediated disease, and to improve the process of risk assessment (Valavanidis and Vlachogianni, 2010). Oxidative stress, is considered as one of the major mechanisms of action of toxicants, and is among the most frequently used biomarkers since it is able to evaluate general damage to biomolecules such as lipids, proteins and DNA (Barata et al., 2005). Oxidative damage to lipids, proteins and DNA and adverse effects on enzymatic antioxidant defence mechanisms in aerobic organisms has been used in recent years as biomarkers for monitoring environmental pollution (Valavanidis et al., 2006). The most important oxidative stress biomarkers used in toxicological studies of aquatic systems are lipid peroxidation (LPX), hydroperoxide content 
(HPC), protein oxidation (PCC), and enzymatic antioxidant defences activity (Dröge, 2003).

Bioindicators can be used to evaluate the toxic impact of contaminants in water bodies. Toxicity studies in fish are one of the most effective methods for understanding the deleterious effects of environmental contaminants in aquatic systems. Fish play a major role in aquatic food webs where they generally occupy an intermediate or higher position: not only are they fed upon by a variety of aquatic predators; they are also a major food source for humans around the world (van der Oost et al., 2003). The common carp (Cyprinus carpio) is commonly used as a bioindicator species, since the cyprinids are quantitatively the most important group of teleost fishes cultured throughout the world for commercial purposes and are also very resistant organisms and easy to maintain (Islas-Flores et al., 2014; Huang et al., 2007).

The aim of this study was to evaluate the toxicity induced by two different concentrations of SUC, ( 0.05 and $\left.155 \mu \mathrm{g} \mathrm{L}^{-1}\right)$ on various organs (brain, gill, blood, liver and kidney) of the freshwater teleost fish $C$. carpio using oxidative stress biomarkers.

\section{Materials and methods}

\subsection{Test substances}

Analytical standard of sucralose, 1,6-dichloro-1,6-dideoxy- $\beta$-Dfructofuranosyl-4-chloro-4-deoxy- $\alpha$-D-galactopyranoside, was purchased from Sigma-Aldrich (St. Louis, MO). Purity of the SUC standard was $\geq 98 \%, \mathrm{C}_{12} \mathrm{H}_{19} \mathrm{Cl}_{3} \mathrm{O}_{8}$, Molecular Weight 397.63 (CAS Number 56038-13-2).

All reagents were HPLC grade. Formic acid for LC-MS analysis was purchased from Merck (Darmstadt, Germany) and nitrogen gas was sourced from INFRA, S.A. de C.V. (DF, Mexico). Ultrapure water was obtained using an ultrapure water purification system provided by Merck Millipore. Acetonitrile was purchased from Sigma-Aldrich.

\subsection{Fish procurement and maintenance}

The bioindicator species (Cyprinus carpio) were obtained from a certified aquaculture facility located in the State of Mexico, and the carps used for this experiment fit for the following characteristics: $19.45 \pm$ $0.53 \mathrm{~cm}$ in length and weight $56.82 \pm 8.3 \mathrm{~g}$. Prior to the toxicity evaluation, organisms were maintained for 40 days in water complemented with salts, at $20 \pm 2{ }^{\circ} \mathrm{C}$ and exposed to natural light/dark photoperiods. Oxygen concentrations was kept above $90 \%, \mathrm{pH}$ at 7.5-8.0, total alkalinity at $17.8 \pm 4.3 \mathrm{mg} \mathrm{L}^{-1}$ and total hardness at $18.0 \pm 0.5 \mathrm{mg} \mathrm{L}^{-1}$.

\subsection{Oxidative stress determination}

All the test systems were prepared using water with the same characteristics and conditions described above in the specimen procurement and maintenance section. The systems used were statics, no food was provided to specimens and no changes in water were made during the experiment.

SUC was tested in two different concentrations ( 0.05 and $155 \mu \mathrm{g}$ $\mathrm{L}^{-1}$ ) for the following exposure periods: $12,24,48,72$, and $96 \mathrm{~h}$, and a SUC free control system was set up for each exposure time. Each system occupies 6 carps and the assays were performed in triplicate (216 fish were used in the oxidative stress evaluation). The target concentrations used in this experiment are based on the environmental water occurrence data of SUC and others sweeteners reported by Arbeláez et al. (2015).

At the end of the exposure period, blood was removed by puncture of the caudal vessel and brain, gill, liver and muscle were removed from each specimen. Organs and tissue were placed in phosphate buffer solution ( $\mathrm{pH} 7.4$ ) and then centrifuged at $12,500 \mathrm{~g}$ and $-4{ }^{\circ} \mathrm{C}$ for $15 \mathrm{~min}$. The following biomarkers were then evaluated: HPC, LPX, PCC and the activity of the antioxidant enzymes superoxide dismutase (SOD) and catalase (CAT). All bioassays were performed on the supernatant.

\subsection{Determination of HPC}

Hydroperoxides content in the samples was measured at $560 \mathrm{~nm}$. $100 \mu \mathrm{L}$ of supernatant was mixed to $900 \mu \mathrm{L}$ of the reaction mixture ( $0.25 \mathrm{mM} \mathrm{FeSO}_{4}, 25 \mathrm{mM} \mathrm{H}_{2} \mathrm{SO}_{4}, 0.1 \mathrm{mM}$ xylenol orange and $4 \mathrm{mM}$ butyl hydroxytoluene in $90 \%(\mathrm{v} / \mathrm{v})$ methanol). After the mixture, samples were incubated for $1 \mathrm{~h}$ at room temperature before its analysis, as described by the Jiang et al. (1992) method. Results were expressed as nanomolar cumene hydroperoxide per milligram of protein.

\subsection{Determination of $L P X$}

Tris-HCl buffer solution ( $\mathrm{pH} 7.4$ ) was added to $100 \mu \mathrm{L}$ of supernatant until a $1 \mathrm{~mL}$ volume was reached; then $2 \mathrm{~mL}$ of TBA-TCA reagent ( $0.375 \%$ thiobarbituric acid in $15 \%$ trichloroacetic acid) was added to this mixture and the solution was shaken in a vortex. Sample preparations then were heated to boiling for $45 \mathrm{~min}$ and immediately cooled at $-5{ }^{\circ} \mathrm{C}$ for the $3 \mathrm{~min}$, followed by a centrifugation at $3000 \mathrm{~g}$ for $10 \mathrm{~min}$. Lipid peroxides were measured in the samples at $535 \mathrm{~nm}$, as described by the Büege and Aust (1978) method. Results were expressed as millimolars of MDA per milligram of protein.

\subsection{Determination of PCC}

$100 \mu \mathrm{L}$ of supernatant was mixed with $150 \mu \mathrm{L}$ of di-nitro phenyl hydrazine (10 $\mathrm{mM}$, dissolved in $\mathrm{HCl} 2 \mathrm{M}$ ), this mixture was incubated for $60 \mathrm{~min}$ at room temperature and protected from the light. The resulting solution was mixed with $500 \mu \mathrm{L}$ of trichloroacetic acid (20\%), and then centrifuged $15 \mathrm{~min}$ later at $1100 \mathrm{~g}$ for $5 \mathrm{~min}$. The resulting bud was washed 4 times with ethanol: ethyl acetate (1:1), followed by its dissolution in $2 \mathrm{~mL}$ of guanidine solution $(6 \mathrm{M}, \mathrm{pH} 2.3)$ and its incubation at $37^{\circ} \mathrm{C}$ for $30 \mathrm{~min}$, as described by the method of Levine et al. (1994) as modified by Parvez and Raisuddin (2005) and Burcham (2007). Protein carbonyl content results were measured at $366 \mathrm{~nm}$ and the results were expressed as micromolar reactive carbonyls formed per milligram of protein.

\subsection{Determination of SOD Activity}

SOD activity was measured at $480 \mathrm{~nm}$ by monitoring changes in the absorbance after $30 \mathrm{~s}$ and $5 \mathrm{~min}$ of the reaction. $40 \mu \mathrm{L}$ of supernatant was added to $260 \mu \mathrm{L}$ of carbonate buffer solution pH 10.2 (50 mM sodium carbonate and $0.1 \mathrm{mM}$ EDTA), plus $200 \mu \mathrm{L}$ adrenaline (30 mM) as described by the Misra and Fridovich (1972) method. Results were expressed as international units per milligram of protein.

\subsection{Determination of CAT activity}

CAT activity was measured at $240 \mathrm{~nm}$ by monitoring for 1 minute the decrease of absorbance of hydrogen peroxide. $20 \mu \mathrm{L}$ of supernatant was mixed with $1 \mathrm{~mL}$ of isolation buffer solution (0.3 M saccharose, $1 \mathrm{~mL}$ EDTA, $5 \mathrm{mM}$ HEPES and $5 \mathrm{mM} \mathrm{KH}_{2} \mathrm{PO}_{4}$ ), plus $0.2 \mathrm{~mL}$ of a hydrogen peroxide solution ( $20 \mathrm{mM}, \mathrm{H}_{2} \mathrm{O}_{2}$ ), as described by Radi et al. (1991). CAT activity were determined in triplicate and expressed as micromolar $\mathrm{H}_{2} \mathrm{O}_{2}$ per milligram of protein.

\subsection{Determination of total protein}

$25 \mu \mathrm{L}$ of supernatant were mixed with $75 \mu \mathrm{L}$ of deionized water and $2.5 \mathrm{~mL}$ Bradford's reagent. The mix was shaken in a vortex for $1 \mathrm{~min}$ and then stored without light for $5 \mathrm{~min}$. Absorbance was read at $595 \mathrm{~nm}$ and the results were interpolated on a bovine albumin curve. Total protein analysis was determined by the Bradford (1976) method. 
2.10. Quantification of SUC by liquid chromatography-tandem mass spectrometry (HPLC-MS/MS)

Stock solution of SUC standard was prepared by dissolution of pure compound in methanol and ultrapure water (50\%/50\%) at a concentration of $1000 \mu \mathrm{g} \mathrm{L}^{-1}$ and then stored at $-20{ }^{\circ} \mathrm{C}$ in amber glass bottles.

The high-performance liquid chromatography (HPLC)-MS/MS system used was an Agilent 1290 Infinity HPLC unit coupled to an Agilent 6430 Triple Quadrupole MS equipped with electrospray ionization (ESI). The injection volume was set to $50 \mu \mathrm{L}$. The separation was performed in gradient elution with ultrapure water acidified with formic acid to $\mathrm{pH} 2.5$ (solvent $\mathrm{A}$ ) and acetonitrile (solvent $\mathrm{B}$ ) as the mobile phase. The gradient started isocratically at $5 \%$ B for 3 min and then increased to $75 \%$ in $6 \mathrm{~min}$, then increased to $100 \%$ in $1 \mathrm{~min}$, remaining constant for $1 \mathrm{~min}$ and finally returning to $5 \% \mathrm{~B}$ in $1 \mathrm{~min}$. The column used was a RRHD Eclipse Plus C18 $(2.1 \times 50 \mathrm{~mm}, 1.8-\mu \mathrm{m})$ with a flow rate of $0.4 \mathrm{~mL} \mathrm{~min}^{-1}$ and the temperature was set at $25^{\circ} \mathrm{C}$. SUC was eluted in less than $8 \mathrm{~min}$. LS-MS/MS analyses were conducted in negative ionization mode using multiple reaction monitoring (MRM) using 395/359 precursor/product ion transitions.

Standard without a column was injected to optimize the conditions of ESI-MS/MS. These conditions were as follows: nebulizer pressure of $45 \mathrm{psi}$, drying gas $\left(\mathrm{N}_{2}\right)$ flow rate of $11 \mathrm{~L} \mathrm{~min}^{-1}$, drying gas temperature of $350{ }^{\circ} \mathrm{C}$ and capillary voltage of $4000 \mathrm{~V}$.

\subsection{Water}

Water samples $(10 \mathrm{~mL})$ were collected from the different test systems in glass vials. Samples were acidified with $1 \mathrm{M} \mathrm{HCl}$ and SUC was extracted from 1-mL water samples with $5 \mathrm{~mL}$ methanol: water (1:1). The mix was centrifuged at $1800 \mathrm{~g}$ for $10 \mathrm{~min}$, and the upper organic layer was used for the analysis by liquid chromatography-tandem mass spectrometry (LC-MS/MS).

\subsection{Plasma}

$5 \mathrm{~mL}$ of ice-cold acetone were added to the plasma samples and then centrifuged at $2500 \mathrm{~g}$ for $5 \mathrm{~min}$. Supernatant was separated and analysed for SUC by LC-MS/MS.

\subsection{Tissues}

$0.2 \mathrm{~g}$ of tissue was homogenized in $4 \mathrm{~mL}$ of methanol: water (1:1), followed by centrifugation at $2500 \mathrm{~g}$ for $5 \mathrm{~min}$. The top layer was carefully separated into clean $10-\mathrm{mL}$ glass vial for its further analysis by liquid chromatography-tandem mass spectrometry (LC-MS/MS).

\subsection{Statistical analysis}

Results of the oxidative stress biomarkers were statistically evaluated by one-way analysis of variance (ANOVA), followed by Bonferroni multiple comparisons test, with $P$ set at $<0.05$. Statistical determinations were performed with SPSS v10 software (SPSS, Chicago IL, USA).

\section{Results}

\subsection{SUC quantification}

Table 1 shows the concentration of SUC in the water systems and in the carp. As can be seen, the SUC concentrations in the water system are decreasing over the time and increasing in the carp's organs and tissues analysed. The organs that have a higher uptake of SUC were the gills and the blood; in the other hand the brain was the organ with the less SUC bio-concentration.

Values are the mean of five replicates $\pm \mathrm{SE}$; ND $=$ Not detected.

\section{2. $H P C$}

HPC results are shown in Fig. 1. Significant increases with respect to the control group $(\mathrm{P}<0.05)$ were observed in the concentration of $0.05 \mu \mathrm{g} \mathrm{L}{ }^{-1}$ at $12,24,48$ and $72 \mathrm{~h}$ in blood, at $48 \mathrm{~h}$ in liver, at $12 \mathrm{~h}$ in gill, at 48 and $72 \mathrm{~h}$ in brain, and finally at 24, 48, 72 and $96 \mathrm{~h}$ in muscle. Furthermore, significant increases with respect to the control group $(\mathrm{P}<0.05)$ were observed in the concentration of $155 \mu \mathrm{g} \mathrm{L}{ }^{-1}$ in blood at $24 \mathrm{~h}$, in liver and gills at 48 and $72 \mathrm{~h}$, and finally at 12, 48 and $72 \mathrm{~h}$ in brain and muscle.

\section{3. $L P X$}

The amount of MDA induced by the SUC is shown in Fig. 2. A significant increase compared to the control group $(\mathrm{P}<0.05)$ was found in blood at 24 and $72 \mathrm{~h}$ in the $0.05 \mu \mathrm{g} \mathrm{L}^{-1}$ concentration and at 12, 24 and $72 \mathrm{~h}$ in the $155 \mu \mathrm{g} \mathrm{L}^{-1}$ concentration. Moreover, a time-dependent increases compared to the control group $(\mathrm{P}<0.05)$ were found at all exposure times in the two concentrations for gill, brain and muscle; except in muscle at $96 \mathrm{~h}$ in $155 \mu \mathrm{g} \mathrm{L}^{-1}$. The most evident increases were observed in brain in $155 \mu \mathrm{g} \mathrm{L}{ }^{-1}$. In the other hand a time-dependent

Table 1

SUC concentrations in the exposure times.

\begin{tabular}{|c|c|c|c|c|c|c|c|}
\hline $\begin{array}{l}\text { Exposure } \\
\text { concentration }\end{array}$ & $\begin{array}{l}\text { Exposure time } \\
\text { (h) }\end{array}$ & $\begin{array}{l}\text { SUC in water system } \\
\left(\mu \mathrm{g} \mathrm{L}^{-1}\right)\end{array}$ & $\begin{array}{l}\text { SUC in blood carp ( } \mu \mathrm{g} \\
\left.\mathrm{L}^{-1}\right)\end{array}$ & $\begin{array}{l}\text { SUC in gill carp } \\
\left(\mu \mathrm{g} \mathrm{g}^{-1}\right)\end{array}$ & $\begin{array}{l}\text { SUC in liver carp ( } \mu \mathrm{g} \\
\left.\mathrm{g}^{-1}\right)\end{array}$ & $\begin{array}{l}\text { SUC in brain carp ( } \mu \mathrm{g} \\
\mathrm{g}^{-1} \text { ) }\end{array}$ & $\begin{array}{l}\text { SUC in muscle carp ( } \mu \mathrm{g} \\
\left.\mathrm{g}^{-1}\right)\end{array}$ \\
\hline \multirow[t]{5}{*}{ Control group } & 12 & ND & ND & ND & ND & ND & ND \\
\hline & 24 & ND & ND & ND & ND & ND & ND \\
\hline & 48 & ND & ND & ND & ND & ND & ND \\
\hline & 72 & ND & ND & ND & ND & ND & ND \\
\hline & 96 & ND & ND & ND & ND & ND & ND \\
\hline \multirow[t]{5}{*}{$0.05 \mu \mathrm{g} \mathrm{L}^{-1}$} & 12 & $0.04 \pm 0.008$ & $0.0010 \pm 0.0001$ & $\begin{array}{l}0.0001 \\
\pm 0.00001\end{array}$ & $\begin{array}{l}0.00009 \\
\pm 0.000001\end{array}$ & ND & ND \\
\hline & 24 & $0.04 \pm 0.007$ & $0.0010 \pm 0.0001$ & $\begin{array}{l}0.0001 \\
\pm 0.00001\end{array}$ & $\begin{array}{l}0.00008 \\
\pm 0.000001\end{array}$ & ND & ND \\
\hline & 48 & $0.03 \pm 0.002$ & $0.0023 \pm 0.0002$ & $\begin{array}{l}0.00028 \\
\pm 0.00002\end{array}$ & $\begin{array}{l}0.00009 \\
\pm 0.000001\end{array}$ & ND & ND \\
\hline & 72 & $0.03 \pm 0.001$ & $0.0042 \pm 0.0003$ & $\begin{array}{l}0.00019 \\
\pm 0.00001\end{array}$ & $\begin{array}{l}0.00011 \\
\pm 0.000001\end{array}$ & $\begin{array}{l}0.00002 \\
\pm 0.0000001\end{array}$ & $0.00003 \pm 0.0000001$ \\
\hline & 96 & $0.02 \pm 0.001$ & $0.0041 \pm 0.0001$ & $\begin{array}{l}0.00031 \\
\pm 0.00001\end{array}$ & $\begin{array}{l}0.00010 \\
\pm 0.000002\end{array}$ & $\begin{array}{l}0.00004 \\
\pm 0.0000001\end{array}$ & $0.00006 \pm 0.0000001$ \\
\hline \multirow[t]{5}{*}{$155 \mu \mathrm{g} \mathrm{L}^{-1}$} & 12 & $132.2 \pm 3.1$ & $6.2 \pm 0.8$ & $2.1 \pm 0.6$ & $0.9 \pm 0.02$ & $0.06 \pm 0.001$ & $0.09 \pm 0.002$ \\
\hline & 24 & $127.5 \pm 1.8$ & $5.8 \pm 1.1$ & $1.9 \pm 0.4$ & $0.9 \pm 0.04$ & $0.07 \pm 0.001$ & $0.08 \pm 0.003$ \\
\hline & 48 & $118.6 \pm 2.1$ & $7.6 \pm 1.2$ & $2.9 \pm 0.6$ & $0.8 \pm 0.07$ & $0.09 \pm 0.002$ & $0.09 \pm 0.001$ \\
\hline & 72 & $112.7 \pm 1.5$ & $8.3 \pm 2.3$ & $3.1 \pm 0.4$ & $1.1 \pm 0.08$ & $0.09 \pm 0.001$ & $0.1 \pm 0.002$ \\
\hline & 96 & $98.3 \pm 2.9$ & $8.1 \pm 1.5$ & $2.8 \pm 0.5$ & $1.4 \pm 0.04$ & $0.09 \pm 0.002$ & $0.16 \pm 0.001$ \\
\hline
\end{tabular}




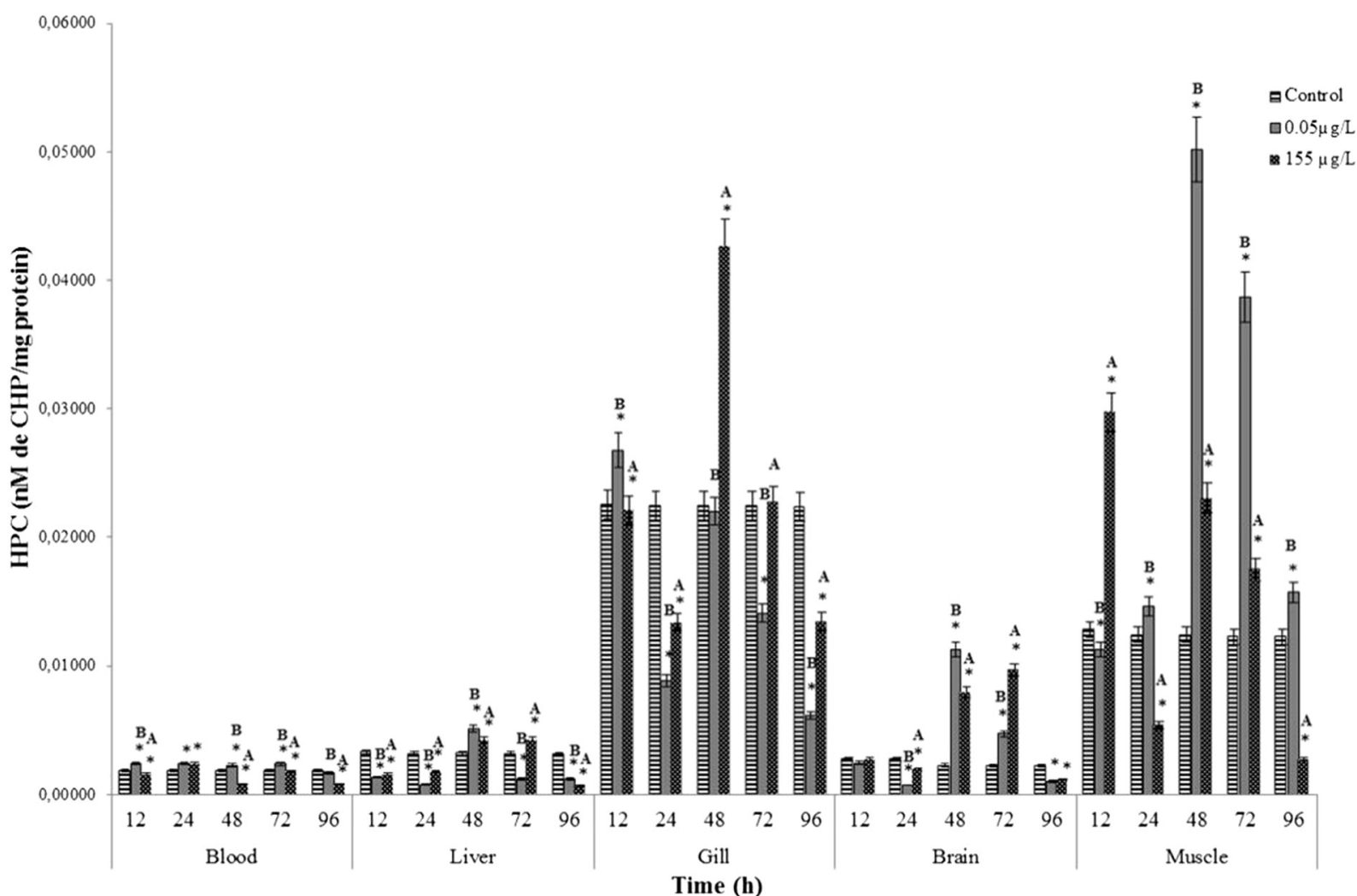

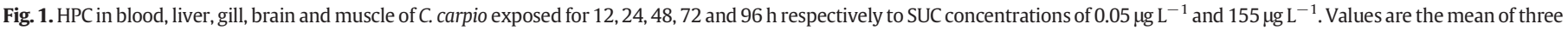
replicates \pm SEM. CHP $=$ cumene hydroperoxide. Significantly different $(P<0.05)$ from: *control values, $A=0.05 \mu g L^{-1}, B=155 \mu g L^{-1} A N O V A$ and Bonferroni's test.

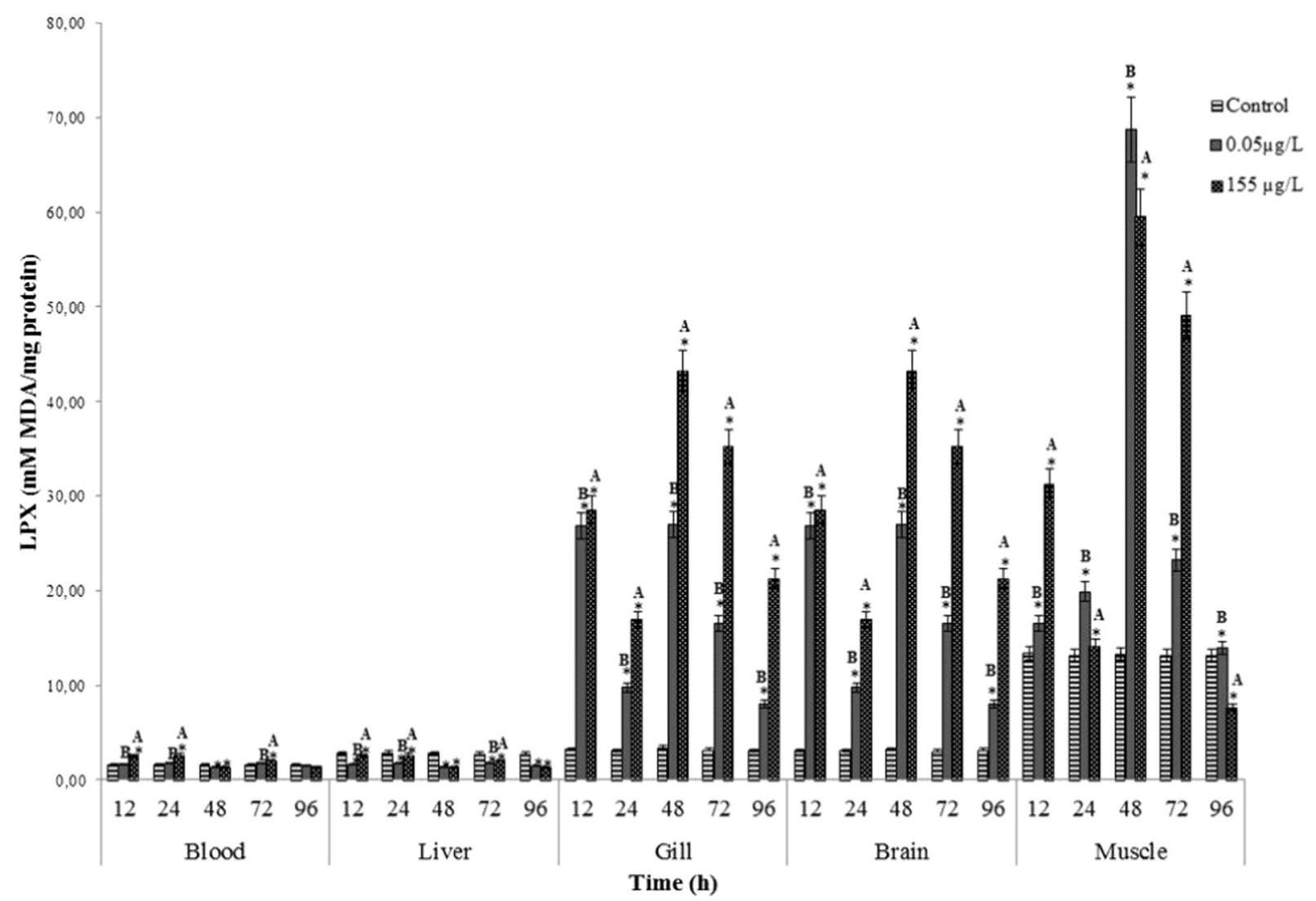

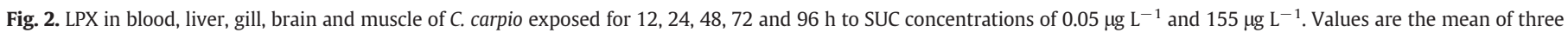
replicates \pm SEM. MDA $=$ malondialdehyde. Significantly different $(\mathrm{P}<0.05)$ from: *control values, $\mathrm{A}=0.05 \mu \mathrm{g} \mathrm{L}{ }^{-1}, \mathrm{~B}=155 \mu \mathrm{g} \mathrm{L}{ }^{-1} \mathrm{ANOVA}$ and Bonferroni's test. 


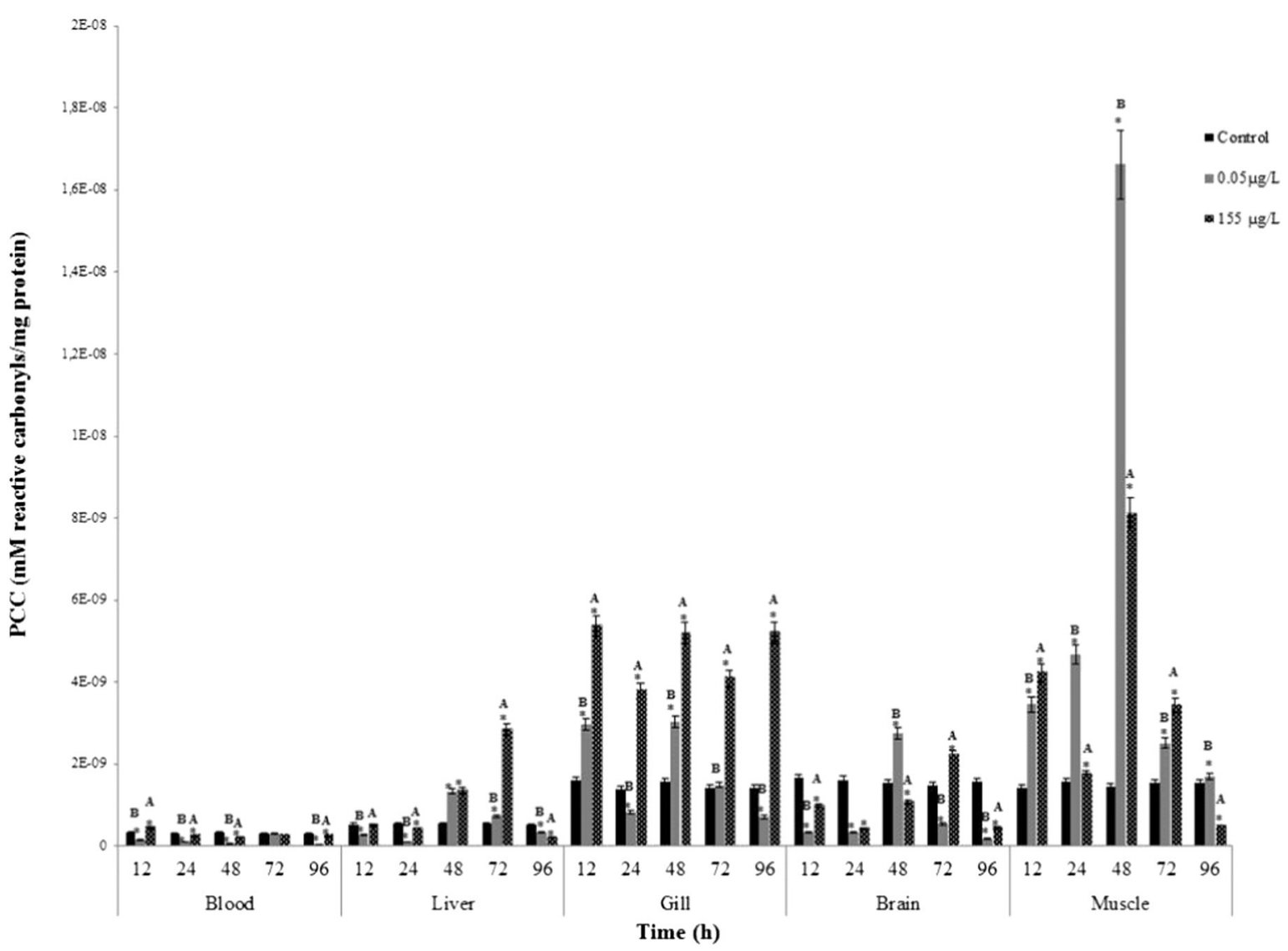

Fig. 3. PCC in blood, liver, gill, brain and muscle of $C$. carpio exposed for 12, 24, 48, 72 and $96 \mathrm{~h}$ to SUC concentrations of $0.05 \mu g \mathrm{~L}^{-1}$ and $155 \mu \mathrm{g} \mathrm{L} \mathrm{L}^{-1}$. Values are the mean of three replicates \pm SEM. Significantly different $(\mathrm{P}<0.05)$ from: * control values, $\mathrm{A}=0.05 \mu \mathrm{g} \mathrm{L}^{-1}, \mathrm{~B}=155 \mu \mathrm{g} \mathrm{L}^{-1}$ ANOVA and Bonferroni's test.

Table 2

Increases and decreases in oxidative stress biomarkers comparing 0.05 and $155 \mu \mathrm{g} \mathrm{L}{ }^{-1}$ against the control group.

\begin{tabular}{|c|c|c|c|c|c|c|c|c|c|c|c|c|c|c|c|c|c|c|c|c|c|}
\hline \multirow[t]{3}{*}{ Organs } & \multirow[t]{3}{*}{ Exposure time $(\mathrm{h})$} & \multicolumn{20}{|c|}{ Oxidative stress biomarkers } \\
\hline & & \multicolumn{4}{|l|}{$\mathrm{HPC}$} & \multicolumn{4}{|l|}{ LPX } & \multicolumn{4}{|l|}{ PCC } & \multicolumn{4}{|l|}{ SOD } & \multicolumn{4}{|l|}{ CAT } \\
\hline & & \multicolumn{2}{|l|}{$\begin{array}{l}0.05 \mu \mathrm{g} \\
\mathrm{L}^{-1}\end{array}$} & \multicolumn{2}{|l|}{$\begin{array}{l}155 \mu \mathrm{g} \\
\mathrm{L}^{-1}\end{array}$} & \multicolumn{2}{|c|}{$0.05 \mu \mathrm{g} \mathrm{L}^{-1}$} & \multicolumn{2}{|c|}{$155 \mu \mathrm{g} \mathrm{L}^{-1}$} & \multicolumn{2}{|c|}{$0.05 \mu \mathrm{g} \mathrm{L}^{-1}$} & \multicolumn{2}{|l|}{$\begin{array}{l}155 \mu \mathrm{g} \\
\mathrm{L}^{-1}\end{array}$} & \multicolumn{2}{|l|}{$\begin{array}{l}0.05 \mu \mathrm{g} \\
\mathrm{L}^{-1}\end{array}$} & \multicolumn{2}{|c|}{$155 \mu \mathrm{g} \mathrm{L} \mathrm{L}^{-1}$} & \multicolumn{2}{|c|}{$0.05 \mu \mathrm{g} \mathrm{L}^{-1}$} & \multicolumn{2}{|c|}{$155 \mu \mathrm{g} \mathrm{L}^{-1}$} \\
\hline \multirow[t]{5}{*}{ Blood } & 12 & $127.9^{*}$ & $\uparrow$ & $17.4^{*}$ & $\downarrow$ & 0.8 & $\downarrow$ & $155.6^{*}$ & $\uparrow$ & $54.3^{*}$ & $\downarrow$ & $135.3^{*}$ & $\uparrow$ & $120.4^{*}$ & $\uparrow$ & $212.7^{*}$ & $\uparrow$ & $124.2^{*}$ & $\uparrow$ & $225.3^{*}$ & $\uparrow$ \\
\hline & 24 & $131.5^{*}$ & $\uparrow$ & $130.9^{*}$ & $\uparrow$ & 107.7 & $\uparrow$ & $161.6^{*}$ & $\uparrow$ & $66.9^{*}$ & $\downarrow$ & $19.8^{*}$ & $\downarrow$ & $52.9^{*}$ & $\downarrow$ & $552.9^{*}$ & $\uparrow$ & $32.6^{*}$ & $\downarrow$ & $268.6^{*}$ & $\uparrow$ \\
\hline & 48 & $122.1^{*}$ & $\uparrow$ & $570^{*}$ & $\downarrow$ & $19.2^{*}$ & $\downarrow$ & $13.6^{*}$ & $\downarrow$ & $82.1^{*}$ & $\downarrow$ & $33.7^{*}$ & $\downarrow$ & 280.9 & $\uparrow$ & $61.3^{*}$ & $\downarrow$ & $183.2^{*}$ & $\uparrow$ & $89.3^{*}$ & $\downarrow$ \\
\hline & 72 & $128.2^{*}$ & $\uparrow$ & $3.1^{*}$ & $\downarrow$ & 108.3 & $\uparrow$ & $124.1^{*}$ & $\uparrow$ & 4.9 & $\downarrow$ & 18.1 & $\downarrow$ & 179.2 & $\uparrow$ & $156.8^{*}$ & $\uparrow$ & $165.5^{*}$ & $\uparrow$ & $92.6^{*}$ & $\downarrow$ \\
\hline & 96 & 8.9 & $\downarrow$ & $55.5^{*}$ & $\downarrow$ & 11.2 & $\downarrow$ & $18.0^{*}$ & $\downarrow$ & $85.3^{*}$ & $\downarrow$ & $18.7^{*}$ & $\downarrow$ & 6.6 & $\downarrow$ & $223.6^{*}$ & $\uparrow$ & $144.9^{*}$ & $\uparrow$ & $86.9^{*}$ & $\downarrow$ \\
\hline \multirow[t]{5}{*}{ Liver } & 12 & $59.9^{*}$ & $\downarrow$ & $53.3^{*}$ & $\downarrow$ & $42.6^{*}$ & $\downarrow$ & $10.0^{*}$ & $\downarrow$ & $49.5^{*}$ & $\downarrow$ & 5.5 & $\downarrow$ & $22.4^{*}$ & $\downarrow$ & $37.2^{*}$ & $\downarrow$ & $48.1^{*}$ & $\downarrow$ & $67.5^{*}$ & $\downarrow$ \\
\hline & 24 & $75.8^{*}$ & $\downarrow$ & $43.7^{*}$ & $\downarrow$ & $39.2^{*}$ & $\downarrow$ & $8.8^{*}$ & $\downarrow$ & $79.6^{*}$ & $\downarrow$ & $23.3^{*}$ & $\downarrow$ & $67.8^{*}$ & $\downarrow$ & $85.2^{*}$ & $\downarrow$ & $69.2^{*}$ & $\downarrow$ & $84.7^{*}$ & $\downarrow$ \\
\hline & 48 & 159.7 & $\uparrow$ & $132.3^{*}$ & $\uparrow$ & $53.5^{*}$ & $\downarrow$ & $50.3^{*}$ & $\downarrow$ & $242.9^{*}$ & $\uparrow$ & $248.0^{*}$ & $\uparrow$ & $980.1^{*}$ & $\uparrow$ & $42.2^{*}$ & $\downarrow$ & $244.7^{*}$ & $\uparrow$ & $167.9^{*}$ & $\uparrow$ \\
\hline & 72 & $62.0^{*}$ & $\downarrow$ & $135.0^{*}$ & $\uparrow$ & $35.3^{*}$ & $\downarrow$ & $25.9^{*}$ & $\downarrow$ & $131.7^{*}$ & $\uparrow$ & 511.1* & $\uparrow$ & $57.1^{*}$ & $\downarrow$ & $1445.1^{*}$ & $\uparrow$ & $66.2^{*}$ & $\downarrow$ & $72.9^{*}$ & $\downarrow$ \\
\hline & 96 & $62.0^{*}$ & $\downarrow$ & $79.0^{*}$ & $\downarrow$ & $48.2^{*}$ & $\downarrow$ & $52.2^{*}$ & $\downarrow$ & $32.5^{*}$ & $\downarrow$ & $59.5^{*}$ & $\downarrow$ & $73.5^{*}$ & $\downarrow$ & 96.7 & $\downarrow$ & $51.2^{*}$ & $\downarrow$ & $91.4^{*}$ & $\downarrow$ \\
\hline \multirow[t]{5}{*}{ Gill } & 12 & 118.6 & $\uparrow$ & $2.1^{*}$ & $\downarrow$ & $829.2^{*}$ & $\uparrow$ & 883.9* & $\uparrow$ & $186.4^{*}$ & $\uparrow$ & $336.4^{*}$ & $\uparrow$ & $627.2^{*}$ & $\uparrow$ & $126.1^{*}$ & $\uparrow$ & $67.0^{*}$ & $\downarrow$ & $105.3^{*}$ & $\uparrow$ \\
\hline & 24 & $60.7^{*}$ & $\downarrow$ & $40.3^{*}$ & $\downarrow$ & $316.5^{*}$ & $\uparrow$ & $548.6^{*}$ & $\uparrow$ & $40.3^{*}$ & $\downarrow$ & $270.8^{*}$ & $\uparrow$ & $84.7^{*}$ & $\downarrow$ & $110.9^{*}$ & $\uparrow$ & $23.0^{*}$ & $\downarrow$ & $54.5^{*}$ & $\downarrow$ \\
\hline & 48 & 2.0 & $\downarrow$ & $189.5^{*}$ & $\uparrow$ & $781.4^{*}$ & $\uparrow$ & $1252.9^{*}$ & $\uparrow$ & $193.0^{*}$ & $\uparrow$ & $330.6^{*}$ & $\uparrow$ & $93.2^{*}$ & $\downarrow$ & $377.5^{*}$ & $\uparrow$ & $206.8^{*}$ & $\uparrow$ & $821.7^{*}$ & $\uparrow$ \\
\hline & 72 & $37.1^{*}$ & $\downarrow$ & 101.7 & $\uparrow$ & $522.7^{*}$ & $\uparrow$ & 1113.3* & $\uparrow$ & 105.6 & $\uparrow$ & $288.9^{*}$ & $\uparrow$ & $37.6^{*}$ & $\downarrow$ & $178.1^{*}$ & $\uparrow$ & $57.5^{*}$ & $\downarrow$ & $9.6^{*}$ & $\downarrow$ \\
\hline & 96 & $72.6^{*}$ & $\downarrow$ & $39.6^{*}$ & $\downarrow$ & $262.6^{*}$ & $\uparrow$ & $693.5^{*}$ & $\uparrow$ & $50.1^{*}$ & $\downarrow$ & $367.6^{*}$ & $\uparrow$ & $213.2^{*}$ & $\uparrow$ & $25.0^{*}$ & $\downarrow$ & $24,8^{*}$ & $\downarrow$ & $361.1^{*}$ & $\uparrow$ \\
\hline \multirow{5}{*}{ Brain } & 12 & 11.8 & $\downarrow$ & 100.2 & $\uparrow$ & $260.6^{*}$ & $\uparrow$ & $782.2^{*}$ & $\uparrow$ & $79.9^{*}$ & $\downarrow$ & $41.0^{*}$ & $\downarrow$ & $120.5^{*}$ & $\uparrow$ & $194.5^{*}$ & $\uparrow$ & $606.0^{*}$ & $\uparrow$ & $294.4^{*}$ & $\uparrow$ \\
\hline & 24 & $73.5^{*}$ & $\downarrow$ & $28.1^{*}$ & $\downarrow$ & $333.5^{*}$ & $\uparrow$ & $754.5^{*}$ & $\uparrow$ & $79.3^{*}$ & $\downarrow$ & $73.4^{*}$ & $\downarrow$ & $70.8^{*}$ & $\downarrow$ & $3.2^{*}$ & $\downarrow$ & 220.5 & $\uparrow$ & 52.2 & $\downarrow$ \\
\hline & 48 & $500.4^{*}$ & $\uparrow$ & $353.3^{*}$ & $\uparrow$ & $3943.4^{*}$ & $\uparrow$ & $2973.5^{*}$ & $\uparrow$ & $175.8^{*}$ & $\uparrow$ & $30.6^{*}$ & $\downarrow$ & $224.8^{*}$ & $\uparrow$ & $384.3^{*}$ & $\uparrow$ & $742.6^{*}$ & $\uparrow$ & $1080.6^{*}$ & $\uparrow$ \\
\hline & 72 & $210.0^{*}$ & $\uparrow$ & $432.5^{*}$ & $\uparrow$ & $623.4^{*}$ & $\uparrow$ & 1079.5* & $\uparrow$ & $63.3^{*}$ & $\downarrow$ & $149.7^{*}$ & $\uparrow$ & 1.6 & $\downarrow$ & $740.2^{*}$ & $\uparrow$ & $2841.7^{*}$ & $\uparrow$ & $2067.2^{*}$ & $\uparrow$ \\
\hline & 96 & $54.9^{*}$ & $\downarrow$ & $49.6^{*}$ & $\downarrow$ & 7451.0* & $\uparrow$ & $4301.7^{*}$ & $\uparrow$ & $88.3^{*}$ & $\downarrow$ & $71.4^{*}$ & $\downarrow$ & $59.2^{*}$ & $\downarrow$ & $49.9^{*}$ & $\downarrow$ & $254.6^{*}$ & $\uparrow$ & $471.6^{*}$ & $\uparrow$ \\
\hline \multirow[t]{5}{*}{ Muscle } & 12 & $12.2^{*}$ & $\downarrow$ & $232.2^{*}$ & $\uparrow$ & $123.8^{*}$ & $\uparrow$ & $233.5^{*}$ & $\uparrow$ & $241.3^{*}$ & $\uparrow$ & $296.0^{*}$ & $\uparrow$ & 104.0 & $\uparrow$ & $692.4^{*}$ & $\uparrow$ & 124.8 & $\uparrow$ & $650.8^{*}$ & $\uparrow$ \\
\hline & 24 & $118.0^{*}$ & $\uparrow$ & $56.5^{*}$ & $\downarrow$ & $151.2^{*}$ & $\uparrow$ & $107.7^{*}$ & $\uparrow$ & $294.6^{*}$ & $\uparrow$ & $111.3^{*}$ & $\uparrow$ & $256.5^{*}$ & $\uparrow$ & $40.6^{*}$ & $\downarrow$ & $298.9^{*}$ & $\uparrow$ & $106.4^{*}$ & $\uparrow$ \\
\hline & 48 & $404.0^{*}$ & $\uparrow$ & $185.8^{*}$ & $\uparrow$ & $517.1^{*}$ & $\uparrow$ & $447.9^{*}$ & $\uparrow$ & $1149.2^{*}$ & $\uparrow$ & $559.5^{*}$ & $\uparrow$ & $476.3^{*}$ & $\uparrow$ & $432.3^{*}$ & $\uparrow$ & $513.6^{*}$ & $\uparrow$ & $890.2^{*}$ & $\uparrow$ \\
\hline & 72 & $315.8^{*}$ & $\uparrow$ & $142.8^{*}$ & $\uparrow$ & $176.0^{*}$ & $\uparrow$ & $372.2^{*}$ & $\uparrow$ & $160.9^{*}$ & $\uparrow$ & $220.7^{*}$ & $\uparrow$ & $288.4^{*}$ & $\uparrow$ & $209.6^{*}$ & $\uparrow$ & $173.4^{*}$ & $\uparrow$ & $367.1^{*}$ & $\uparrow$ \\
\hline & 96 & $128.2^{*}$ & $\uparrow$ & $77.6^{*}$ & $\downarrow$ & 106.0* & $\uparrow$ & $41.7^{*}$ & $\downarrow$ & $110.9^{*}$ & $\uparrow$ & $68.7^{*}$ & $\downarrow$ & $21.2^{*}$ & $\downarrow$ & $13.0^{*}$ & $\downarrow$ & $209.2^{*}$ & $\uparrow$ & $1942.5^{*}$ & $\uparrow$ \\
\hline
\end{tabular}




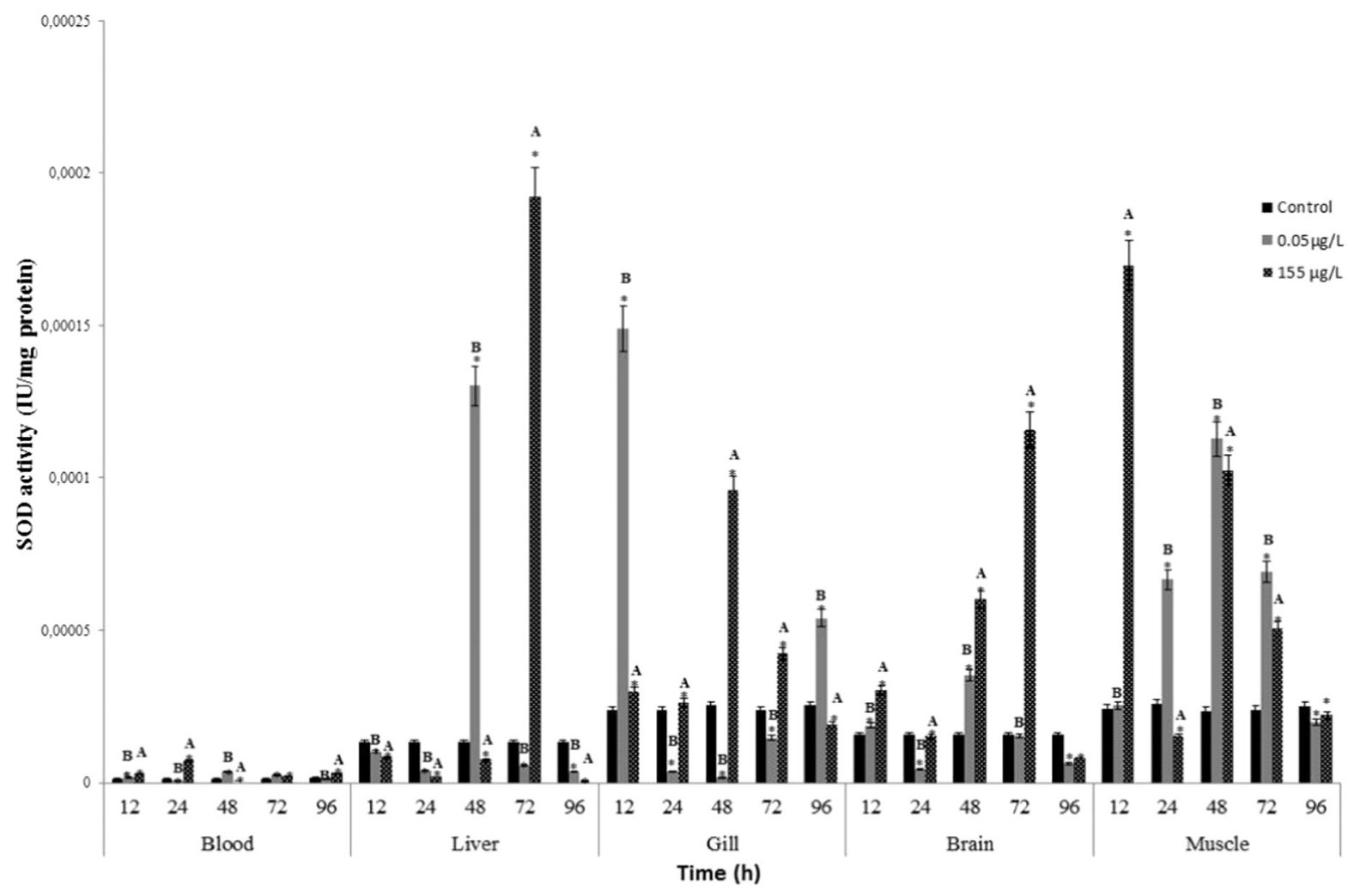

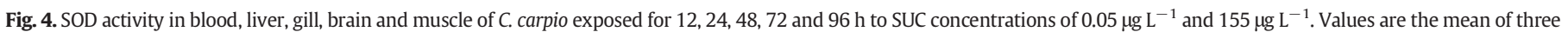
replicates \pm SEM. Significantly different $(\mathrm{P}<0.05)$ from: *control values, $A=0.05 \mu \mathrm{g} \mathrm{L}^{-1}, \mathrm{~B}=155 \mu \mathrm{g} \mathrm{L}^{-1}$ ANOVA and Bonferroni's test.

decreases compared to the control group $(\mathrm{P}<0.05)$ were found at all exposure times in the two concentrations for the liver.

\subsection{PCC}

PCC results are shown in Fig. 3. A significant increase with respect to the control group $(\mathrm{P}<0.05)$ was found for the blood at $12 \mathrm{~h}$ in the $155 \mu \mathrm{g}$ $\mathrm{L}^{-1}$ concentration, for the liver at 48 and $72 \mathrm{~h}$ for both concentrations, in the gill at 12,48 and $72 \mathrm{~h}$ for the $0.05 \mu \mathrm{g} \mathrm{L}{ }^{-1}$ concentration and at 12,24 , 48,72 and $96 \mathrm{~h}$ for the $155 \mu \mathrm{g} \mathrm{L}{ }^{-1}$ concentration, in brain at $48 \mathrm{~h}$ in the $0.05 \mu \mathrm{g} \mathrm{L}^{-1}$ concentration and at $72 \mathrm{~h}$ for the $155 \mu \mathrm{g} \mathrm{L} \mathrm{L}^{-1}$ concentration and finally in muscle in all the exposure times for the $0.05 \mu \mathrm{g} \mathrm{L}^{-1}$ concentration and at $12,24,48$ and $72 \mathrm{~h}$ for the $155 \mu \mathrm{g} \mathrm{L} \mathrm{L}^{-1}$ concentration (Table 2).

\subsection{SOD}

SOD results are shown in Fig. 4. Significant increases with respect to the control group $(\mathrm{P}<0.05)$ were observed in the concentration of $0.05 \mu \mathrm{g} \mathrm{L} \mathrm{L}^{-1}$ at 12,48 and $72 \mathrm{~h}$ in the blood, at $48 \mathrm{~h}$ for the liver, at 12 and $96 \mathrm{~h}$ for the gills, at 12 and $48 \mathrm{~h}$ in brain, and finally at 12, 24, 48 and $72 \mathrm{~h}$ for the muscle. Furthermore, significant increases with respect to the control group $(\mathrm{P}<0.05)$ were observed in the concentration of $155 \mu \mathrm{g} \mathrm{L}{ }^{-1}$ at $12,24,72$ and $96 \mathrm{~h}$ in the blood, at $72 \mathrm{~h}$ for the liver, at $12,24,48$ and $72 \mathrm{~h}$ for the gill, and finally at 12,48 and $72 \mathrm{~h}$ for the brain and muscle respectively.

\subsection{CAT}

CAT activity results are shown in Fig. 5. Significant increases with respect to the control group $(\mathrm{P}<0.05)$ were observed for the $0.05 \mu \mathrm{g} \mathrm{L}^{-1}$ concentration, at $12,48,72$ and $96 \mathrm{~h}$ in blood, at $48 \mathrm{~h}$ in the liver and gills, and at all exposure times for the brain and muscle. Furthermore, significant increases with respect to the control group $(\mathrm{P}<0.05)$ were observed in the concentration of $155 \mu \mathrm{g} \mathrm{L}^{-1}$ at 12 and $24 \mathrm{~h}$ for the blood, at $48 \mathrm{~h}$ in the liver, at 12, 48 and $96 \mathrm{~h}$ in the gills, at 12, 48, 72 and $96 \mathrm{~h}$ in the brain, an finally at all the exposures times in the muscle.

\section{Discussion}

The wide and high consumption of SUC around the globe, have result in different scientific reports that described its occurrence in different water bodies at concentrations ranging from 0.1 to $1.0 \mathrm{~g} \mathrm{~L}^{-1}$ (Eriksson-Wiklund et al., 2014; Lange et al., 2012; Minten and Adolfsson-Erici, 2011; Loos et al., 2009), moreover this artificial sweetener poses a high stability under different conditions, which may have consequences over different aquatic species. However, the present state of knowledge is still unable to comprehend fully the possible ecotoxicological risk that this compound may pose.

SUC poses three chloro groups on its structure, which makes it resistant against different conditions. Particularly this molecule has been reported to be persistent against different digestive enzymes responsible of the hydrolysis in the gut (European Commission, 2000). Likewise, SUC has been considered as an stable compound under several environmental conditions; Grice and Goldsmith (2000) reported that SUC was expected to be intact within one year at a pH 4 and 6; likewise Grotz et al. (2012) reported that over a storage time of five years there was no chemical changes in a buffered solution of SUC at $\mathrm{pH} 4.4$; moreover The European Commission (2000) described that after six months of storage only a $0.3 \%$ of hydrolysis was reported in a solution of SUC at $\mathrm{pH} 3$.

Its high stability and resistance to hydrolysis may result on its bioconcentration in different organs and tissues. The analytic results obtained in this study shows that for the $155 \mu^{\mathrm{g} \mathrm{L}^{-1}}$ concentration, SUC was detected and quantified in all the exposure times and in all the organs and tissues tested, with the highest concentrations detected within 48-72 h, and quantified in the organs in the following decreasing order, blood, gill, liver, muscle, and brain. By the same way for the 


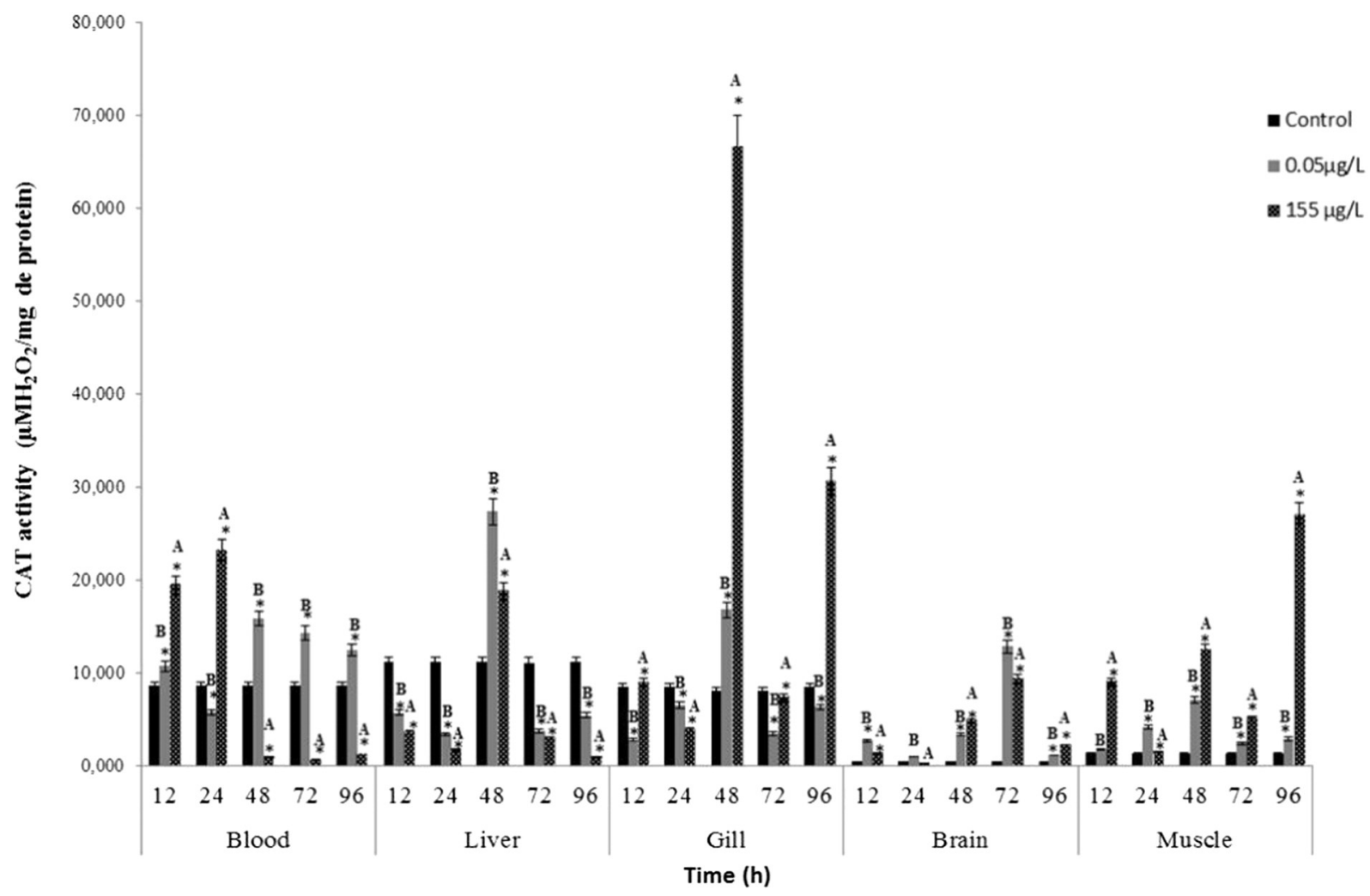

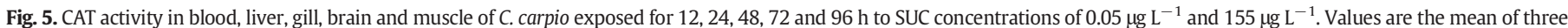
replicates \pm SEM. Significantly different $(p<0.05)$ from: *control values, $A=0.05 \mu \mathrm{g} \mathrm{L}^{-1}, \mathrm{~B}=155 \mu \mathrm{g} \mathrm{L}^{-1}$ ANOVA and Bonferroni's test.

$0.05 \mu \mathrm{g} \mathrm{L}{ }^{-1}$ concentration, SUC was detected in all the exposure times in the blood, gill and liver, and only between 72 and $96 \mathrm{~h}$ in the brain and muscle; the highest concentrations detected were within 72-96 h, and was quantified in the organs in the following decreasing order, blood, gill, liver, muscle and brain. However, with low-octanol water partitioning coefficient $\left(-0.49^{2}\right)$ and a structure full of hydroxyl groups, SUC poses a low bioaccumulation potential (Tollefsen et al., 2012). The reviewed literature stated that SUC does not accumulate significantly in different aquatic organisms tissues, with a bioaccumulation factors (BCF) lower than the criteria set to identify it as persistent in species as Danio rerio, Pseudokirchneriella subcapitata and Daphnia magna (Lillicrap et al., 2009a, b; Lillicrap et al., 2011). Our results are in agreement with the above, due to in the bigger concentration $\left(155 \mu \mathrm{g} \mathrm{L}^{-1}\right)$ only $12.55 \mu \mathrm{g}$ (8.1\%) were accumulated in the different organs and tissues analysed, which means a BCF of 0.1276; likewise in the lower concentration $\left(0.05 \mu \mathrm{g} \mathrm{L}^{-1}\right)$ only $0.00461 \mu \mathrm{g}(9.22 \%)$ were accumulated in the different organs and tissues analysed, which means a BCF of 0.0922 . For both concentrations, the BCF results obtained in this study for the uptake of SUC were below than the unit, which means that SUC does not accumulate significantly in the different organs and tissues of Cyprinus carpio.

Regarding with the toxicology of SUC, in the recent decades it has been tested in different aquatic organisms (Lemna gibba, Calanus glacialis, Calanus finmarchicus, Pseudokirchneirella subcapita, Daphnia magna, Danio rerio) resulting always in negligible adverse acute/chronic toxic effects as well as in low bio-concentration factor (Soh et al., 2011; Lillicrap et al., 2011; Hjorth et al., 2010); however Eriksson et al. (2012) reported that SUC modifies the swimming behaviour in Daphnia magna as well as modifies the time to reach food and the shelter time in Gammarus oceanicus and Gammarus zaddachi, moreover ErikssonWiklund et al. (2014) report that SUC induce neurological and oxidative damage with potentially important consequences for animal behaviour and physiology. However the present knowledge and scientific data until now is insufficient to demonstrate its environmental innocuity.
To our knowledge this is the first study examining the oxidative stress produced by SUC in aquatic species. Our analytic results demonstrate that SUC was present in the water media and within the carp during the whole experiment, thereby the changes in the enzymatic activity (SOD, CAT) and the damages to the biomolecules (LPX, HPC, PCC) described in the result section are directly related to the presence of this artificial sweetener. Our results indicate a significant elevation in the activity of SOD and CAT enzymes in all the organs and tissues analysed, for the SOD activity the organ with the highest activity was the muscle followed by the liver, gill and brain in a decreasing order; the blood was the only tissue with negligible SOD activity; in the other hand, for the CAT activity the organ with the highest activity was the gill, followed by the liver, blood, muscle and brain in a decreasing order. An increase in the activity of CAT and SOD enzymes has been reported in the face of different environmental pollutants (Elizalde-Velázquez et al., 2016; SanJuan-Reyes et al., 2015; Islas-Flores et al., 2014, García-Medina et al., 2013; Islas-Flores et al., 2013a, 2014; SanJuan-Reyes et al., 2013; Garcia-Medina et al., 2010), since SOD and CAT enzymes represents the major reactive oxygen species (ROS) scavenging mechanisms and thereby the first line of defence against oxidative stress.

The scientific literature report that less than $10 \%$ of the initial dosage of SUC is metabolized in two different metabolites as glucuronide conjugates of SUC; 4-chloro-4-deoxy-galactose (4-CG) and 1,6-dichloro-1,6dideoxy-fructose (1,6-DCF) (Sims et al., 2000; Roberts et al., 2000; Grice and Goldsmith, 2000). Moreover, Abou-Donia et al. (2008) described that SUC elevated the expression of P-gp and CYP (CYP3A, CYP2D) enzymes in the gastrointestinal tract of rats at doses approved by the FDA and EU. The CYP subfamily CYP3A is reported to have specificity over organochlorine drugs therefore the organochlorine sweetener SUC could be a substrate for this CYP enzyme (Schiffman and Rother, 2013; Higashikawa et al., 1999). In this context, it is noteworthy that the CYP superfamily are related also with the intestinal metabolism of different compounds, contributing significantly to the first pass effect 
and therefore with the decrease in the concentration of the xenobiotics (Schiffman and Rother, 2013; Paine, 2009; Paine et al., 2006; Paine and Thummel, 2003; Hall et al., 1999). Fishes are capable of xenobiotic metabolism by microsomal oxidation, reduction and conjugation; indeed the enzyme characteristics are similar between fishes and mammals (Chambers and Yarbrough, 1976), particularly the CYP subfamily CYP3A has been reported to be present in liver, intestines, blood and brain of rainbow trout (Oncorhynchus mykiss), killifish (Fundulus heteroclitus), medaka (Oryzias latipes), and common carp (Cyprinus carpio) (González-Mantilla, 2006; Thibaut et al., 2006; Kashiwada et al., 2005; Hegelund and Celander, 2003; Lee and Buhler, 2003; Buhler and Wang-Buhler, 1998; Celander and Stegeman, 1997). Likewise the glucuronidation process in teleost fishes as carps have been reported to play an important role in the hepatic detoxification of different xenobiotics (Yokota et al., 2002; George, 1994; Clarke et al., 1991; Forlin and Haux, 1985), therefore it is possible that SUC could be metabolized by oxidation and glucuronidation processes in the carp.

Cytochromes $\mathrm{P} 450$ are responsible for the biotransformation of most xenobiotics as well as participate actively in the elimination of foreign chemicals from the body, however these enzymes has an important consequence related to its activity since these enzymes reduce molecular oxygen to produce prooxidant species, which, if are not countered efficiently by antioxidants, create oxidative stress. Since the cells have a high content of the microsomal monooxygenase system, and the microsomal electron transfer chain is one of the main sources of ROS, its activity has been associated to cytotoxicity, genotoxicity, oxidative stress, carcinogenesis, drug toxicity, and the pathogenesis of several diseases (González, 2005; Davydov, 2001; Robertson et al., 2001; Bondy and Naderi, 1994). In a recent study Eriksson et al. (2014) reported that the exposure of Daphnia magna to SUC induces oxidative mechanisms with potentially important consequences for animal behaviour and physiology. They measured the oxygen radical absorbing capacity (ORAC), which represent the level of antioxidant defences, and they found an increase in the values of this biomarker. Therefore the biotransformation process mediated by the microsomal monooxygenase system and the CYP enzymes with the consequent release of ROS, could explain the increase in the SOD and CAT activities described above in this study.

Another possible explanation could be related with the energy regulation; Swithers et al. $(2008,2009,2010)$ reported that consumption of high potency sweeteners interfered with the ability of sweet taste to predict caloric consequences and therefore disrupted energy regulation (Schiffman and Rother, 2013; Swithers et al., 2010, 2009; Swithers and Davidson, 2008). The sweet taste cues have been reliable predictors of energy density of food, however artificial sweeteners like SUC have negligible utilizable calories, which uncouple the relation between sensory properties of foods and their caloric content (Schiffman and Rother, 2013). Sugar receptors have been found in Cyprinus carpio (Hidaka and Yokota, 1967), thereby the carp could likely sense the artificial sweetener SUC dissolved in the water serving as a cue for food intake. Eriksson et al. (2014) stated that exposure of Daphnia magna to SUC stimulates feeding and increase caloric intake that may also predispose test animals to oxidative stress. In this context, Pepino et al. (2013) reported that SUC increase glucose and insulin levels in obese women, as well as different authors also have reported that SUC modulates glucose and insulin secretion in rodents (Nakawaga et al., 2009; Mace et al., 2007). Brief episodes of hyperglycemia cause tissue damage by mechanisms involving repeated acute changes in cellular metabolism; Rolo and Palmeira (2006) number some key metabolic pathways as major contributors to hyperglycemia induce tissue damage: by increasing the polyol pathway flux and by increasing the advanced glycation end product (AGE). The increase in the polyol pathway flux decreases the NADPH and glutathione equivalents, which enhance sensitivity to intracellular ROS (Brownlee, 2001). The production of advanced glycation end product (AGE) precursor interferes with the cell integrity by inducing receptor-mediated production of ROS (Yan et al., 1994). Additionally
Nishikawa et al. (2000b) reported that hyperglycemia induced the overproduction of superoxide in the mitochondria. Therefore the disruption in the energy regulation due to an increase of glucose and insulin levels induced by SUC involves the production and release of intracellular ROS, which also could explain the increase in the SOD and CAT activities described above in this study.

An increased ROS production not only involves an increase in the antioxidant enzymes levels it may also cause cell damage by attacking biomolecules as lipids and proteins, resulting in an increase in LPX and in the oxidized protein content (Gómez-Oliván et al., 2014; Shacter, 2000). In our study we use the HPC and LPX as molecular biomarkers to assess the damage of lipids and both of them were modified due to the presence of these artificial sweetener; the organs that showed more damage were gills, brain and muscle; in the other hand blood and liver showed a negligible effect for this two biomarkers related with the presence of SUC. Likewise, we use the PCC molecular biomarker to measure the damage to proteins, as well as in the HPC and LPX results, the organs that showed more damage were gills, muscle, brain, but also liver showed an increase in the protein carbonylation content, however, the blood again showed a negligible effect for this molecular biomarker. Our results are in agreement with the reports of ErikssonWiklund et al. (2014) who stated that SUC induce lipid peroxidation in Daphnia magna after it exposure to SUC. Gills are the main organs in intimate contact with the water media and consequently with the xenobiotics, thereby are likely to be target for aquatic pollutants, additionally gills are known to be a site with a high oxidative metabolism and a site of expression of the cytochrome isoform CYP3A, promoting the production of ROS and consequently the oxidative damage (Gómez-Oliván et al., 2014; Uno et al., 2012; Monteiro et al., 2005). The brain as well as the nervous systems are inadequately equipped with antioxidant defence systems to prevent oxidative damage therefore are prone to oxidative stress, in this context Eriksson-Wiklund et al. (2014), reported that exposure to SUC may induce neurological and oxidative mechanisms, since they observed a stimulating effect of SUC on the acetylcholinesterase (AChE) activity of Daphnia magna; scientific literature reported that elevated activity of AChE has been linked to neurodegenerative diseases as Alzheimer's disease, Parkinson disease's, multiple sclerosis and restless leg syndrome (RLS) (Eriksson-Wiklund et al., 2014; Akaike et al., 2010; Toiber and Soreq, 2005). Skeletal muscles poses high oxidative metabolism since this organ uses high quantities of oxygen and large amounts of energy to do their functions (Ferrari et al., 1997). Wiklund et al. (2012) reported that SUC altered the swimming behaviour of Daphnia magna, which results in increased energy spending and induce high metabolic costs, thereby inducing the production of ROS. Muscles are made of proteins and aminoacids, which are target of ROS; direct damage to proteins or chemical modifications of aminoacids and proteins during oxidative stress, can give rise to protein carbonyls (Parvez and Raisuddin, 2005).

More experimental studies are needed in different aquatic species that involve the use of different molecular biomarkers, as well as different studies as cytotoxicity and genotoxocity to fully understand the ecotoxicological risk associated with the presence of this artificial sweetener in the environmental water bodies, since the present study shows that SUC modifies the normal antioxidant enzymatic activity and induce oxidative damage in lipids and proteins of Cyprinus carpio.

\section{Conclusion}

SUC possesses a low BCF (less than the unit for both test concentrations) which means that this organochlorine compound does not accumulate in the organs and tissues of Cyprinus carpio. In both concentrations the higher values of SUC were recorded between 48 and $96 \mathrm{~h}$ after it exposition, being the blood the tissues with the higher SUC concentrations and the brain with the less values for this sweetener. SUC modified the normal antioxidant enzyme level and induce oxidative damage in lipids and proteins of Cyprinus carpio, the organs which 
showed more damage were gills, muscle, brain and liver in decreasing order, and the blood was the only tissue with negligible affects. The set of assays used in the present study could be effectively used as potential biomarkers to measure the toxicity of AMX for the freshwater fish in the field of environmental biomonitoring, as well as also constitutes a reliable early warning biomarker for the use in the evaluation of the toxicity induced by these emerging contaminants on aquatic species.

\section{References}

Abou-Donia, M.B., El-Masry, E.M., Abdel-Rahman, A.A., McLendon, R.E., Schiffman, S.S., 2008. Splenda alters gut microflora and increases intestinal P-glycoprotein and cytochrome P450 in male rats. J. Toxicol. Environ. Health A 71, 1415-1429. http://dx.doi. org/10.1080/15287390802328630

Ahmed, F.E., Thomas, D.B., 1992. Assessment of the carcinogenicity of the nonnutritive sweetener cyclamate. Crit. Rev. Toxicol. 229 (2), 81-118. http://dx.doi.org/10.3109/ 10408449209146307.

Akaike, A., Takada-Takatori, Y., Kume, T., Izumi, Y., 2010. Mechanisms of Neuroprotective Effects of Nicotine and Acetylcholinesterase Inhibitors: Role of a 4 and a7 Receptors in Neuroprotection. J. J. Mol Neurosci 40, 211-216. http://dx.doi.org/10.1007/s12031009-9236-1.

Arbeláez, P., Borull, F., Pocurull, E., Marcé, R.M., 2015. Determination of high-intensity sweeteners in river water and wastewater by solid-phase extraction and liquid chromatography-tandem mass spectrometry. J. Chromatogr A 1393, 106-114. http://dx. doi.org/10.1016/j.chroma.2015.03.035.

Barata, C., Varo, I., Navaro, J.C., Arum, S., Porte, C., 2005. Antioxidant enzyme activities and lipid peroxidation in the freshwater cladoceran Daphnia magna exposed to redox cycling compounds. Comp. Biochem. Physiol C. Toxicol. Pharmacol. 140, 175-186 doi: 10.1016/j.cca.2005.01.013.

Bennett, D., 2008. The Intense Sweetener World, Ehrenberg Centre for Research in Marketing. http://www.lsbu.ac.uk/bus-ehrenberg/ documents/High Intensity Sweeteners.pdf.

Bondy, S.C., Naderi, S., 1994. Contribution of hepatic cytochrome P450 systems to the generation of reactive oxygen species. Biochem. Pharmacol. 48, 155-159. http://dx.doi. org/10.1016/0006-2952(94)90235-6.

Bradford, M.M., 1976. A rapid and sensitive method for the quantitation of microgram quantities of protein utilizing the principle of protein-dye binding. Anal. Biochem. 72 (1), 248-254. http://dx.doi.org/10.1016/0003-2697(76)90527-3.

Brorstrom-Lunden, E., Svenson, A., Viktor, T., Woldegiorgis, A., Remberger, M., Kai, L., Dye, C., Bjerke, A., Schlabach, M., 2008. Measurements of sucralose in the Swedish screening pogram 2007 - part 2: Sucralose in biota and regional STP samples. IVL Report B1795. Sweden, Swedish Environmental Research Institute, Stockholm.

Brownlee, M., 2001. Biochemistry and molecular cell biology of diabetic complications. Nature 414, 813-820. http://dx.doi.org/10.1038/414813a.

Brusick, D., Grotz, V.L., Slesinki, R., Kruger, C.L., Hayes, A.W., 2010. The absence of genotoxicity of sucralose. Food Chem. Toxicol. 48 (11), 3067-3072. http://dx.doi. org/10.1016/j.fct.2010.07.047.

Büege, J.A., Aust, S.D., 1978. Microsomal lipid peroxidation. Methods Enzymol. 52, 302-310. http://dx.doi.org/10.1016/S0076-6879(78)52032-6.

Buhler, D.R., Wang-Buhler, J.-L., 1998. Rainbow trout cytochrome P450s: purification, molecular aspects, metabolic activity, induction and role in environmental monitoring. Comp. Biochem. Physiol. C 121, 107-137. http://dx.doi.org/10.1016/S07428413(98)10033-6.

Burcham, P.C., 2007. Modified protein carbonyl assay detects oxidised membrane proteins: A new tool for assessing drug- and chemically-induced oxidative cell injury. J. Pharmacol. Toxicol. 56 (1), 18-22. http://dx.doi.org/10.1016/j.vascn. 2006.02.015.

Celander, M.C., Stegeman, J.J., 1997. Isolation of a cytochrome P4503A cDNA sequence (CYP3A30) from the marine teleost Fundulus heteroclitus and phylogenetic analyses of CYP3A genes. Biochem. Biophys. Res. Commun. 236, 306-312. http://dx.doi.org/10. 1006/bbrc.1997.6956.

Chambers, J.E., Yarbrough, J.D., 1976. Xenobiotic biotransformation systems in fishes. Comparative Biochemistry and Physiology Part C: Comparative Pharmacology 55 (2), 77-84. http://dx.doi.org/10.1016/0306-4492(76)90027-7.

Clarke, D.J., George, S.G., Burchell, B., 1991. Glucuronidation in fish. Aquat. Toxicol. 20, 35-56.

Cohen, S.M., Arnold, L.L., Emerson, J.L., 2008. Safety of saccharin. Agro Food Industry Hitech 19 (6), 24-28.

Davydov, D.R., 2001. Microsomal monooxygenase in apoptosis: another target for cytochrome c signaling? Trends Biochem. Sci. 26 (3), 155-160. http://dx.doi.org/10. 1016/S0968-0004(00)01749-7.

Dröge, W., 2003. Free radicals in the physiological control of cell functions. Physiol. Rev. 439, 47-95. http://dx.doi.org/10.1152/physrev.00018.2001.

Elizalde-Velázquez, A., Galar-Martínez, M., Dublán-García, O., Gómez-Oliván, L.M., Rodríguez-Flores, J., Castañeda-Peñalvo, G., 2016. Effect of amoxicillin exposure on brain, gill, liver and kidney of common carp Cyprinus carpio using oxidative stress biomarkers. Environmental Toxicology, Journal Citation Reports (JCR) In Press.

Eriksson-Wiklund, A.K., Adolfsson-Erici, M., Liewenborg, B., Gorokhova, E., 2014. Sucralose induces biochemical responses in Daphnia magna. PLoS ONE 9 (4), e92771. http://dx.doi.org/10.1371/journal.pone.0092771.

European Commission, 2000. Scientific Committee on Food (SCF), Opinion of the Scientific Committee on Food on sucralose-SCF/CS/ADDS/EDUL/190 Final. http://ec.europa. eu/food/fs/sc/scf/out68_en.pdf. (accessed 6.06.2016).
Ferrari, M., Binzoni, T., Quaresima, V., 1997. Oxidative metabolism in muscle. Philosophical Transactions of the Royal Society of London B: Biological Sciences 352 (1354), 677-683. http://dx.doi.org/10.1098/rstb.1997.0049.

Ferrer, I., Thurman, E.M., 2010. Analysis of sucralose and other sweeteners in water and beverage samples by liquid chromatography/time-of-flight mass spectrometry. J. Chromatogr. A 1217, 4127-4134. http://dx.doi.org/10.1016/j.chroma.2010.02.020.

Forlin, L., Haux, C., 1985. Increased excretion in the bile of $17 \mathrm{~b}-(3 \mathrm{H})$ estradiol-derived radioactivity in rainbow trout treated with beta-naph-tophavolen. Aquat. Toxicol. 6 197-208. http://dx.doi.org/10.1016/0166-445X(85)90004-9.

García-Medina, S., Razo-Estrada, A.C., Gómez-Oliván, L.M., Amaya-Chavez, A., Madrigal-Bujaidar, E., Galar-Martínez, M., 2010. Aluminum-induced oxidative stress in lymphocytes of common carp Cyprinus carpio. Fish Physiol. Biochem. 36 (4), 875-882.

García-Medina, S., Nuñez-Betancourt, J.A., García-Medina, A., Galar-Martínez, M., NeriCruz, N., Islas-Flores, H., Gómez-Oliván, L.M., 2013. The relationship of cytotoxic and genotoxic damage with blood aluminum levels and oxidative stress induced by this metal in common carp Cyprinus carpio erythrocytes. Ecotoxicol. Environ. Saf 96, 191-197. http://dx.doi.org/10.1016/j.ecoenv.2013.06.010.

George, S.G., 1994. Enzymology and molecular biliology of phase II xenobiotic-conjugating enzymes in fish. In: Malins, D.C., Ostrander, G.K. (Eds.), Aquatic toxicology: molecular, biochemical and cellular perspectives. CRC Press, USA, pp. 37-85.

Gómez-Oliván, L.M., Galar-Martínez, M., García-Medina, S., Valdés-Alanís, M., Islas-Flores, H., Neri-Cruz, N., 2014. Genotoxic response and oxidative stress induced by diclofenac, ibuprofen and naproxen in Daphnia magna. Drug Chem. Toxicol. 1-9 Early Online. doi:10.3109/01480545.2013.870191.

González, F.J., 2005. Role of cytochromes P450 in chemical toxicity and oxidative stress: studies with CYP2E1. Mutation Research/Fundamental and Molecular Mechanisms of Mutagenesis 569 (1), 101-110. http://dx.doi.org/10.1016/j.mrfmmm.2004.04.021.

González-Mantilla, J.F., 2006. Hepatic phase I and II biotransformation kinetics in fishes: a comparative study. Thesis dissertation Doctor of Philosophy, University of Maryland, pp. 1-228.

Grice, H.C., Goldsmith, L.A., 2000. Sucralose- an overview of the toxicity data. Food Chem. Toxicol. 38 (Suppl. 2), S1-S6. http://dx.doi.org/10.1016/j.yrtph.2009.05.011.

Grotz, V.L., Munro, I.C., 2009. An overview of the safety of sucralose. Regul. Toxicol. Pharmacol. 55 (1), 1-5. http://dx.doi.org/10.1016/j.yrtph.2009.05.011.

Grotz, V.L., Molinary, S., Peterson, R.C., 2012. Sucralose, in Alternative Sweeteners (ed L. O Brien Nabors). CRC Press Taylor and Francis Group, Boca Raton.

Haely, S., 2012. Sugar and Sweeteners Outlook. ResearchGate Retrieved September 6, 2016, from. https://www.researchgate.net/publication/228781824_Sugar_and sweeteners_outlook. (March 14).

Hall, S.D., Thummel, K.E., Watkins, P.E., Lown, K.S., Benet, L.Z., Paine, M.F., Mayo, R.R., Turgeon, D.K., Bailey, D.G., Fontana, R.J., Wrighton, S.A., 1999. Molecular and physical mechanisms of first-pass extraction. Drug Metab. Dispos. 27, 161-166.

Hegelund, T., Celander, M.C., 2003. Hepatic versus extrahepatic expression of CYP3A30 and CYP3A56 in adult killifish (Fundulus heteroclitus). Aquat. Toxicol. 64, 277-291. http://dx.doi.org/10.1016/S0166-445X(03)00057-2.

Hidaka, I., Yokota, S., 1967. Taste receptor stimulation by sweet taste substances in the carp. The Japanese Journal of Physiology 17 (6), 652-666.

Higashikawa, F., Murakami, T., Kaneda, T., Kato, A., Takano, M., 1999. Dose-dependent intestinal and hepatic first pass metabolism of midazolam, a cytochrome P450 3A substrate with differently modulated enzyme activity in rats. J. Pharm. Pharmacol. 51, 67-72. http://dx.doi.org/10.1211/0022357991771971.

Hjorth, M., Hansen, J.H., Camus, L., 2010. Short-term effects of sucralose on Calanus finmarchicus and Calanus glacialis in Disko Bay. Greenland. Chem. Ecol. 26, 385-393. http://dx.doi.org/10.1080/02757540.2010.504672.

Houtman, C.J., 2010. Emerging contaminants in surface waters and their relevance for the production of drinking water in Europe. J. Integr. Environ. Sci. 7 (4), 271-295. http:// dx.doi.org/10.1080/1943815X.2010.511648.

Huang, D.J., Zhang, Y.M., Song, G., Long, J., Liu, J.H., Ji, W.H., 2007. Contaminants induced oxidative damage on the carp Cyprinus carpio collected from the upper Yellow River, China. Environ. Monit. Assess. 128 (1-3), 483-488.

Huggett, D.B., Stoddard, K.I., 2011. Effects of the artificial sweetener sucralose on Daphnic magna and Americamysis bahia survival, growth and reproduction. Food Chem. Toxicol. 49, 2575-2579. http://dx.doi.org/10.1016/j.fct.2011.06.073.

Islas-Flores, H., Gómez-Oliván, L.M., Galar-Martínez, M., Colin-Cruz, A., Neri-Cruz, N. García-Medina, S., 2013a. Diclofenac-induced oxidative stress in brain, liver, gill and blood of common carp Cyprinus carpio. Ecotoxicol. Environ. Saf. 92, 32-38. http:// dx.doi.org/10.1016/j.ecoenv.2013.01.025.

Islas-Flores, H., Gómez-Oliván, L.M., Galar-Martínez, M., García-Medina, S., NeriCruz, N., Dublan-García, O., 2014. Effect of ibuprofen exposure on blood, gill, liver, and brain on common carp Cyprinus carpio using oxidative stress biomarkers. Environ. Sci. Pollut. Res. 21 (7), 5157-5166. http://dx.doi.org/10. 1007/s11356-013-2477-0.

Jiang, Z.Y., Hunt, J.V., Wolff, S.P., 1992. Ferrous ion oxidation in the presence of xylenol orange for detection of lipid hydroperoxide in low density lipoprotein. Anal. Biochem. 202 (2), 384-389. http://dx.doi.org/10.1016/0003-2697(92)90122-N.

Kashiwada, S., Hinton, D.E., Kullman, S.W., 2005. Functional characterization of medaka CYP3A38 and CYP3A40: kinetics and catalysis by expression in a recombinant baculovirus system. Comp. Biochem. Physiol. C 141, 338-348. http://dx.doi.org/10. 1016/j.cca.2005.07.006.

Kokotou, M.G., Asimakopoulus, A.G., Thomaidis, S., 2012. Artificial sweeteners as emerging pollutants in the environment: analytical methodologies and environmental impact. Anal. Methods 4, 3057-3070. http://dx.doi.org/10.1039/C2AY05950A.

Kroger, M., Meister, K., Kava, R., 2006. Low-calorie sweeteners and other sugar substitutes: a review of the safety issues. Compr. Rev. Food Sci. Food Saf. 5, 35-47. http:// dx.doi.org/10.1111/j.1541-4337.2006.tb00081.x. 
Lange, F.T., Scheurer, M., Brauch, H.J., 2012. Artificial sweetenersda recently recognized class of emerging environmental contaminants: a review. Anal. Bioanal. Chem. 403 (9), 2503-2518. http://dx.doi.org/10.1007/s00216-012-5892-z.

Lee, S.J., Buhler, D.R., 2003. Cloning, tissue distribution, and functional studies of a new cytochrome P4503A subfamily member, CYP3A45, from rainbow trout (Oncorhynchus mykiss) intestinal ceca. Arch. Biochem. Biophys. 412, 77-89. http://dx.doi.org/10. 1016/S0003-9861(03)00029-8.

Levine, R.L., Williams, J.A., Stadtman, E.R., Shacter, E., 1994. Carbonyl assays for determination of oxidatively modified proteins. Methods Enzymol. 233, 346-357. http://dx.doi. org/10.1016/S0076-6879(94)33040-9.

Lillicrap, A., Langford, K., Brooks, S., Tollefsen, K., 2009a. Determination of the bioaccumulation and elimination of sucralose in the zebrafish Danio rerio.

Lillicrap, A., Langford, K., Brooks, S., Tollefsen, K., 2009b. Determination of the bioaccumulation of sucralose on the freshwater alga Pseudokirchneriella subcapitata.

Lillicrap, A., Langford, K., Tollefsen, K.E., 2011. Bioconcentration of the intense sweetene sucralose in a multitrophic battery of aquatic organisms. Environ. Toxicol. Chem. 30, 673-681. http://dx.doi.org/10.1002/etc.433.

Loos, R., Gawlik, B.M., Boettcher, K., Locoro, G., Contini, S., Bidoglio, G., 2009. Sucralose screening in European surface waters using a solid-phase extraction-liquid chromatography-triple quadrupole mass spectrometry method. J. Chromatogr. A 1216 1126-1131. http://dx.doi.org/10.1016/j.chroma.2008.12.048.

Mace, O.J., Affleck, J., Patel, N., Kellett, G.L., 2007. Sweet taste receptors in rat small intestine stimulate glucose absorption through apical GLUT2. J. Physiol. 582, 379-392. http://dx.doi.org/10.1113/jphysiol.2007.130906.

Minten, J., Adolfsson-Erici, M., Bjo rlenius, B., Alsberg, T., 2011. A method for the analysis of sucralose with electrospray LC/MS in recipient waters and in sewage effluent subjected to tertiary treatment technologies. Int. J. Environ. Anal. Chem. 91, 357-366. http://dx.doi.org/10.1080/03067310903582333.

Misra, H.P., Fridovich, I., 1972. The role of superoxide anion in the autoxidation of epinephrine and a simple assay for superoxide dismutase. J. Biol. Chem. 247 (10), 3170-3175. http://dx.doi.org/10.1080/03067310903582333.

Monteiro, S.M., Mancera, J.M., Fontaínhas-Fernandes, A., Sausa, M., 2005. Copper- induced alterations of biochemical parameters in the gill and plasma of Oreochromis niloticus. Comp. Physiol. Biochem. 141 (C), 375-383. http://dx.doi.org/10.1016/j.cbpc.2005.08. 002.

Nakagawa, Y., Nawasaka, M., Yamada, S., Hara, A., Mogami, H., Nikolaev, V.O., Lohse, M.J. Shigemura, N., Ninomiya, Y., Kojima, I., 2009. Sweet taste receptor expressed in pancreatic $\beta$-cells activates the calcium and cyclic AMP signalling systems and stimulates insulin secretion. PLoS One 4, e5106. http://dx.doi.org/10.1371/journal.pone. 0005106.

Neset, T.S., Singer, H., Longrée, P., Bader, H.P., Scheidegger, R., Wittmer, A., Andersson, J.C. 2010. Understanding consumption-related sucralose emissions - A conceptual approach combining substance-flow analysis with sampling analysis. Sci. Total Environ. 408, 3261-3269. http://dx.doi.org/10.1016/j.scitotenv.2010.04.003.

Nishikawa, T., Edelstein, D., Brownlee, M., 2000b. The missing link: a single unifying mechanism for diabetic complications. Kidney Int. 58, S26-S30.

Paine, M.F., 2009. Sites of extra hepatic metabolism, Part II: Gut. In: Pearson, P.G Wienkers, L.C. (Eds.), Handbook of rug metabolism, $2^{\text {nd }}$ ed. Informa Healthcare USA, New York, NY, pp. 273-298.

Paine, M.F. Thummel, K.E., M.B., F. 2003. Role of intestinal cytochrome P450 in drug disposition. In: Lee, J.S., Obach, R.S. (Eds.), Drug metabolizing enzymes: cytochrome P450 and other enzymes in drug discovery and development. Marcel Dekker, New York, N.Y., pp. 421-452.

Paine, M.F., Hart, H.L., Ludington, S.S., Haining, R.L., Rettie, A.E., Zeldin, D.C., 2006. The human intestinal cytochrome P450 "pie". Drug Metab. Dispos. 34, 880-886.

Parvez, S., Raisuddin, S., 2005. Protein carbonyls: novel biomarkers of exposure to oxidative stress-inducing pesticides in freshwater fish Channa punctata (Bloch). Environ. Toxicol. Pharmacol. 20 (1), 112-117. http://dx.doi.org/10.1016/j.etap.2004.11.002.

Pepino, M.Y., Tiemann, C.D., Patterson, B.W., Wice, B.M., Klein, S., 2013. Sucralose affects glycemic and hormonal responses to an oral glucose load. Diabetes care 36 , 2530-2535. http://dx.doi.org/10.2337/dc12-2221.

Radi, R., Turrens, J.F., Chang, L.Y., Bush, K.M., Crapo, J.D., Freeman, B.A., 1991. Detection of catalase in rat heart mitochondria. J. Biol. Chem. 266 (32), 22028-22034.

Richardson, S.D., 2010. Environmental mass spectrometry: emerging contamiants and current issues. Anal. Chem. 82 (12), 4742-4774. http://dx.doi.org/10.1021/ ac800660d.

Richardson, S.D., Ternes, T.A., 2011. Water analysis: emerging contaminants and current issues. Anal. Chem. 83, 4621-4648. http://dx.doi.org/10.1021/ac9008012.

Roberts, A., Renwick, A.G., Sims, J., Snodin, D.J., 2000. Sucralose metabolism and pharmacokinetics in man. Food Chem. Toxicol. 38 (Suppl 2), S31-S41. http://dx.doi.org/10. 1016/S0278-6915(00)00026-0.

Robertson, G., Leclercq, I., Farrell, G.C., 2001. Cytochrome P-450 enzymes and oxidative stress. American Journal of Physiology-Gastrointestinal and Liver Physiology 281 (5), G1135-G1139.
Rolo, A.P., Palmeira, C.M., 2006. Diabetes and mitochondrial function: role of hyperglycemia and oxidative stress. Toxicol. Appl. Pharmacol. 212 (2), 167-178. http://dx.doi. org/10.1016/j.taap.2006.01.003

Sang, Z., Jiang, Y., Tsoi, Y.K., Leung, K.S.Y., 2014. Evaluating the environmental impact of artificial sweeteners: A study of their distributions, photodegradation and toxicities. Water Res. 52, 260-274. http://dx.doi.org/10.1016/j.watres.2013.11.002.

SanJuan-Reyes, N., Gómez-Oliván, L.M., Galar-Martínez, M., Vieyra-Reyes, P., GarcíaMedina, S., Islas-Flores, $\mathrm{H}$, Neri-Cruz, N , 2013. Effluent from an NSAID-manufacturing plant in mexico induces oxidative stress on Cyprinus carpio. Water Air Soil Pollut. 224 (9). http://dx.doi.org/10.1007/s11270-013-1689-8.

SanJuan-Reyes, N., Gómez-Oliván, L.M., Galar-Martínez, M., García-Medina, S., Islas-Flores, H., Gonález-González, E.D., Cardoso-Vera, D., Jiménez-Vargas, J.M., 2015. NSAIDmanufacturing plant effluent induces geno- and cytotoxicity in common carp Cyprinus carpio. Sci. Total Environ. 530-531, 1-10. http://dx.doi.org/10.1016/j. scitotenv.2015.05.088.

Scheurer, M., Brauch, H.J., Lange, F.T., 2009. Analysis and occurrence of seven artificial sweeteners in German waste water and surface water and in soil aquifer treatment (SAT). Anal. Bioanal. Chem. 394, 1585-1594. http://dx.doi.org/10.1007/s00216-0092881-y.

Schiffman, S.S., Rother, K.I., 2013. Sucralose, a synthetic organochlorine sweetener: overview of biological issues. J. Toxicol. Environ. Health B Crit. Rev. 16 (7), 399-451. http://dx.doi.org/10.1080/10937404.2013.842523.

Shacter, E., 2000. Quantification and significance of protein oxidation in biological samples. Drug Metab. Rev. 32, 307-326. http://dx.doi.org/10.1081/DMR-100102336.

Sims, J., Roberts, A., Daniel, J.W., Renwick, A.G., 2000. The metabolic fate of sucralose in rats. Food Chem. Toxicol. 38, 115-121. http://dx.doi.org/10.1016/S02786915(00)00034-X.

Soh, L., Connors, K.A., Brooks, B.W., Zimmerman, J., 2011. Fate of sucralose through environmental and water treatment processes and impact on plant indicator species. Environ. Sci. Technol. 45, 1363-1369. http://dx.doi.org/10.1021/es102719d.

Swithers, S.E., Davidson, T.L., 2008. A role for sweet taste: Calorie predictive relations in energy regulation by rats. Behav. Neurosci. 122, 161-173. http://dx.doi.org/10. 1037/0735-7044.122.1.161.

Swithers, S.E., Baker, C.R., Davidson, T.L., 2009. General and persistent effects of high-intensity sweeteners on body weight gain and caloric compensation in rats. Behav, Neurosci. 123, 772-780.

Swithers, S.E., Martin, A.A., Davidson, T.L., 2010. High-intensity sweeteners and energy balance. Physiol. Behav. 100, 55-62. http://dx.doi.org/10.1037/a0016139.

Thibaut, R., Schnell, S., Porte, C., 2006. The interference of pharmaceuticals with endogenous and xenobiotic metabolizing enzymes in carp liver: an in vitro study. Environ. Sci. Technol. 40, 5154-5160. http://dx.doi.org/10.1021/es0607483.

Toiber, D., Soreq, H., 2005. Cellular stress reactions as putative cholinergic links in Alzheimer's disease. Neurochem. Res. 30, 909-919. http://dx.doi.org/10.1007/ s11064-005-6963-8.

Tollefsen, K.E., Nizzetto, L., Huggett, D.B., 2012. Presence, fate and effects of the intense sweetener sucralose in the aquatic environment. Sci. Total Environ. 438, 510-516. http://dx.doi.org/10.1016/j.scitotenv.2012.08.060.

Uno, T., Ishizuka, M., Itakura, T., 2012. Cytochrome P450 (CYP) in fish. Environ Toxicol. Pharmacol. 34 (1), 1-13. http://dx.doi.org/10.1016/j.etap.2012.02.004.

Valavanidis, A., Vlachogianni, T., 2010. Integrated biomarkers in aquatic organisms as a tool for biomonitoring environmental pollution and improved ecological risk assessment. Sci. Adv. Environ. Toxicol. Ecotoxicol. 10, 325-333.

Valavanidis, A., Vlahogianni, T., Dassenakis, M., Scoullos, M., 2006. Molecular biomarkers of oxidative stress in aquatic organisms in relation to toxic environmental pollutants. Ecotoxicol. Environ. Saf. 64, 178-189. http://dx.doi.org/10.1016/j.ecoenv.2005.03. 013.

van der Oost, R., Beyer, J., Vermeulen, N.P., 2003. Fish bioaccumulation and biomarkers in environmental risk assessment: a review. Environ. Toxicol. Pharmacol. 13 (2), 57-149. http://dx.doi.org/10.1016/S1382-6689(02)00126-6.

Viberg, H., Fredriksson, A., 2011. Neonatal exposure to sucralose does not alter biochemical markers of neuronal development or adult behaviour. Nutrition 27 (1), 81-85. http://dx.doi.org/10.1016/j.nut.2009.10.007.

Weihrauch, M.R., Diehl, V., 2004. Artificial sweeteners-do they bear a carcinogenic risk? Ann. Oncologia 15 (10), 1460-1465.

Yan, S.D., Schmidt, A.M., Anderson, G.M., Zhang, J., Brett, J., Zou, Y.S., Pinsky, D., Stern, D., 1994. Enhanced cellular oxidant stress by the interaction of advanced glycation end products with their receptors/binding proteins. J. Biol. Chem. 269, 9889-9897.

Yokota, H., Miyashita, N., Yuasa, A., 2002. High glucuronidation activity of environmental estrogens in the carp Cyprinus carpio intestine. Life Sci. 71 (8), 887-898. http://dx.doi. org/10.1016/S0024-3205(02)01767-8.

Zygler, A., Wasik, A., Namiesnik, J., 2009. Analytical methodologies for determination of artificial sweeteners in foodstuffs. TrAC Trends Anal. Chem. 28 (9), 1082-1102. http://dx.doi.org/10.1016/j.trac.2009.06.008. 